Enzo Solari

Escuela de Derecho

Universidad Católica del Norte

\title{
Los presupuestos filosóficos de la teología cristiana según Zubiri
}

En estas páginas me propongo no exponer la teología llevada a cabo por Zubiri, sino tan solo abordar aquellas cuestiones teológicas que dicen relación con su filosofía de la religión. Intento, así, ofrecer de manera unitaria la visión de Zubiri en torno a las presuposiciones filosóficas del quehacer teológico característicamente cristiano. De ahí las cuatro cuestiones que habrán de examinarse: el privilegio del cristianismo, su núcleo esencial, el lógos cristiano, y las posibles vinculaciones del cristianismo con la filosofía.

\section{EL CRISTIANISMO Y LAS RELIGIONES}

En un plano teológico, Zubiri afirma inequívocamente el privilegio del cristianismo. Si toda religión tiene algo de verdad, la cristiana es la verdad definitiva y suprema de todas las religiones, y por ello se puede decir que es la religión verdadera (1). Esto significa que las demás religiones, e incluso las actitudes no teístas, llegan realmente al Dios cristiano porque acceden, aun desviadamente, a él (2). De ahí la frase de Zubiri:

"el budista o el brahmán no llegan al Dios cristiano a pesar de ser budistas o brahmanes, sino en la medida en que son buenos budistas y buenos brahmanes, y justamente por serlo. Entonces el cuerpo objetivo de la religión tiene un valor intrínseco de acceso al Dios del cristianismo, y no solamente los individuos en razón de su buena fe" (3).

La desviación propia de las demás religiones ya no es una mera 'aberración', sino una 'deformidad' medida por su real aproximación al cristianismo. En mayor o

(1) Vid. Zubiri, El problema filosófico de la historia de las religiones (Madrid, Alianza 1993), pp. 329-330, y El problema teologal del hombre: cristianismo (Madrid, Alianza 1997), pp. 614-616.

(2) Vid. Zubiri, Historia (n. 1), p. 331.

(3) Zubiri, Historia (n. 1), p. 331.

(4) Vid. Zubiri, Historia (n. 1), pp. 332 y 334; Cristianismo (n. 1), pp. 76 y 616. 
menor medida, toda religión (e irreligión) sería, así, 'cristianismo deforme' (4). La deformidad cristiana de las religiones no implica sincretismo ninguno, como tampoco que las religiones sean una suerte de deformación histórica del cristianismo. Dicha deformidad supone, más bien, la transcendencia histórica del cristianismo (5). Claro que esta es una transcendencia visible solo para quien tiene fe: "la transcendencia histórica del cristianismo [...] no pasa de ser un signo, un semeîon, frente al cual el hombre tendrá que optar" (6). Así entendida, la transcendencia cristiana es la presencia no solo fragmentada del cristianismo en las religiones, sino "aquello en que consiste la verdad positiva de todas ellas" (7). El cristianismo está en las religiones pero superándolas, de modo que lo que ellas tienen de verdaderas es la misma verdad del cristianismo:

"desde un punto de vista teológico, las demás religiones no han sido queridas por Dios más que en la medida en que son, de una manera 'deforme' y 'aberrante', la realización misma del cristianismo" (8).

Esta aberración alcanza incluso a las restantes vías monoteístas, particularmente al judaísmo y al islam. El monoteísmo judío, que es aceptable para el cristianismo y está incorporado en él, sin embargo, no puede aceptar el punto de vista cristiano con su proclamación no nacional sino estrictamente universal de la Encarnación divina: he ahí su yerro. A su vez, la desviación del monoteísmo islámico consiste en que se trata de una regresión religiosa respecto al cristianismo, ya que tampoco puede aceptar la personalidad divina de Jesús al no ver en él más que un profeta más. Estas son, sin lugar a duda, unas tesis formalmente teológicas, pues suponen la verdad de la revelación cristiana, y no son conquistadas al cabo de una confrontación filosófica, de una investigación confesionalmente libre:

"[...] ante estos tres monoteísmos, evidentemente, no hay razón especulativa ninguna para optar. Es simplemente una opción de fe. Es el pálpito de las vías reales y efectivas por las que el monoteísmo ha sido viable a lo largo de la historia" (9).

A su manera, sin saberlo, cada religión lleva en sí misma al cristianismo y es, por tanto, un cristianismo intrínseco: "toda religión es un cristianismo 'deforme', y por consiguiente lleva una 'formidad' -sit venia verbo- intrínseca de carácter formalmente cristiano" (10). Y no solo las religiones. Zubiri recuerda que según san Pablo todo ser humano apunta al Dios desconocido, ágnostos theós (cf. Hch 17, 23), busca a Dios a tientas, pselaphân tòn theón (cf. Hch 17, 27): es "la humanidad buscando a tientas a Dios, pero justamente al Dios cristiano, y accediendo irrecusa-

(5) Vid. Zubiri, Historia (n. 1), pp. 335-338; Cristianismo (n. 1), p. 63.

(6) Zubiri, Historia (n. 1), p. 336.

(7) Zubiri, Historia (n. 1), p. 336.

(8) Zubiri, Historia (n. 1), p. 337. Por ello "todas las religiones son verdaderas en tanto en cuanto que, en una o en otra forma, son cristianismo": Cristianismo (n. 1), p. 614.

(9) Zubiri, Historia (n. 1), p. 230

(10) Zubiri, Historia (n. 1), p. 337. 
blemente a él" (11). Por la verdad cristiana, toda religión es (más o menos) verdadera: "el cristianismo es la verdad incorporada a las demás religiones" (12).

Por supuesto, la viabilidad del cristianismo -como la de toda religión- tiene su especificidad. Es cierto que en ocasiones Zubiri juzga históricamente al cristianismo no solo por su especificidad religiosa sino también por sus consecuencias o virtualidades culturales. Alguna vez, en efecto, habla de las grandes creaciones del espíritu humano: la religión de Israel, la metafísica griega, el derecho romano y la ciencia moderna, añadiendo que "el haberlos absorbido en una unidad radical y transcendente, constituye una de las manifestaciones históricas más espléndidas de las posibilidades internas del cristianismo" (13). Esta, como se ve, es una declaración casi hegeliana: el rango privilegiado del cristianismo radicaría justamente en lo que ha dado de sí en la historia, pero en el preciso sentido de que seguir al cristianismo equivale prácticamente a seguir el majestuoso curso objetivo del espíritu absoluto. Sin embargo, no parece ser esta la opinión prevaleciente de Zubiri. De hecho, ese texto casi juvenil resulta desmentido por sus propios cursos y textos maduros. Por ejemplo, Zubiri dice expresamente que

"la verdad cristiana irá indefectiblemente conquistando espíritus. Ahora bien, esto no significa que el mundo irá haciéndose cristiano [Mundo no tiene aquí el estricto significado de respectividad de lo real qua real sino el sentido menos preciso pero más frecuente del conjunto de tópicos y usos vigentes que 'se' practican en una sociedad]. Todo lo contrario. Probablemente el Apocalipsis de san Juan nos abre las puertas de una vía distinta: no se trata de una marcha triunfal del cristianismo, tal vez larga y penosa, pero en definitiva ejecutiva, al término de la cual el mundo terminará siendo formalmente cristiano en cuanto mundo. Esto no está dicho en ninguna parte. Probablemente la visión más interna del Apocalipsis es justamente la inversa: el mundo no será cristiano; habrá muchos cristianos, pero al margen del mundo que, como tal, no será cristiano. Al mundo le pasará lo que le pasó a Cristo: que murió en la cruz. Un mundo que no será cristiano: habrá muchos cristianos, pero solo al margen de su mundo. En esta forma es como Cristo estará con nosotros hasta la consumación de los siglos (cf. Mt 28, 20). El cristianismo no actúa sobre los espíritus tan solo por la existencia triunfante de un cuerpo objetivo dentro de una sociedad políticamente organizada. Justamente al revés: el cristianismo actúa en profundidad" (14).

En 1971, Zubiri vuelve sobre esto añadiendo que la misión del cristianismo, conforme a la cual puede y debe ser juzgado históricamente, no consiste en unas genéricas tareas culturales (pese a todo el valor que ellas puedan poseer), sino en su peculiaridad religiosa:

(11) Vid. Zubiri, Historia (n. 1), p. 334

(12) Zubiri, Historia (n. 1), p. 339.

(13) Zubiri, Naturaleza, Historia, Dios (Madrid, Alianza 2004), p. 29.

(14) Zubiri, Historia (n. 1), pp. 345-346. La misma idea está desarrollada en el curso sobre el problema del mal; vid. Zubiri, Sobre el sentimiento y la volición (Madrid, Alianza 1992), pp. 318-319. 
"el cristianismo no tiene por misión (dígase lo que se quiera) crear formas de cultura y de civilización. Esto es absurdo. Son todas ellas caducas como caduco es el hombre que las ha engendrado. La misión del cristianismo es otra: es llevar todas las civilizaciones a Dios, que es cosa distinta" (15).

En todo caso, la versión teológica que ofrece Zubiri de la verdad cristiana no se confunde con cualquiera afirmación de la misma. Por un lado, Zubiri se separa de la tesis que enfatiza que la verdad religiosa es patrimonio exclusivo del cristianismo. Todo hombre, ha dicho, tiene acceso real a Dios, y no hay vías religiosas completamente falsas. Por esto "la actitud del cristianismo frente a las demás religiones no podrá ser nunca la de una afirmación excluyente" (16). Por el otro, se aparta de la tesis para la cual la religión cristiana, aunque es jerárquicamente superior a todas las religiones, sin embargo, admite la verdad de ellas por estar todas situadas en una misma línea. No se llega al cristianismo por un mero desarrollo lineal de las tendencias de otras vías religiosas, pues la religión cristiana implica una ruptura radical, una peculiaridad. Es cierto que Zubiri acepta que hay una cierta continuidad entre el cristianismo, las demás religiones e, incluso, las posiciones no teístas, porque todas son opciones tomadas ante un problema común, que es el problema de Dios. Esta continuidad es ante todo campal, por basarse en el análisis según el cual toda religión (e irreligión) es plasmación particular de la religación, pero es también (aunque más estrechamente) metafísica, por resultar de una explicación de la religación que destaca el mejor derecho racional de cualquiera imagen monoteísta de la divinidad. Empero, según Zubiri no hay mera continuidad entre el cristianismo y las demás religiones y experiencias fundamentales. Esta especificidad del cristianismo solo aparece cuando entra en juego la mentalidad del creyente, sea del sentido común, sea propiamente teológica. La perspectiva de Zubiri, claro, es teológica, es el punto de vista de la razón científica confesionalmente comprometida. Teológicamente es como Zubiri afirma sin ambages la discontinuidad entre el cristianismo y las demás opciones fundamentales, teístas y no teístas. Si se reúnen estas dos características del cristianismo, 1) ser la religión definitivamente verdadera y esencialmente distinta de las demás religiones, y 2) ser a la vez la verdad interna de todas ellas, de tal modo que las religiones son a su manera verdaderas en cuanto cristianismo deforme, intrínseco e ignorado, entonces se puede decir que la posición teológica de Zubiri

(15) Zubiri, Cristianismo (n. 1), p. 85.

(16) Zubiri, Historia (n. 1), p. 340. Y agrega: "esto habrá podido ocurrir miles de veces en el curso de la historia, pero siempre de una manera irregular y contraria a la propia esencia del cristianismo": Historia (n. 1), p. 340 .

(17) Las clasificaciones usuales distinguen entre exclusivismo, inclusivismo y pluralismo; vid. Ratzinger, $F e$, verdad y tolerancia (trad. C. Ruiz-Garrido, Salamanca, Sígueme 2005), pp. 44-47; Berger, Una gloria lejana. La búsqueda de la fe en época de credulidad (trad. J. A. Iglesias, Barcelona, Herder 1994), pp. 185-192, y Berger, Cuestiones sobre la fe. Una afirmación escéptica del cristianismo (trad. M. Villanueva, Barcelona, Herder 2006), pp. 34-40. Según ellas, Zubiri es un inclusivista. Aquí me baso especialmente en la tipología elaborada por Bernhardt, conforme a la cual la postura de Zubiri corresponde al modelo de la dualidad inclusivista. Para Bernhardt, la defensa de la pretensión de absolutez del cristianismo (der Absolutheitsanspruch des Christentums) conoce tres modelos. A) El modelo dualista de la validez única y exclusiva (vid. Bernhardt 
respecto a la verdad cristiana es al mismo tiempo dualista e inclusiva (17). En sus propios términos, la actitud del cristianismo hacia las demás religiones es "una actitud de versión positiva hacia ellas" (18). Esto no implica tanto que el cristianismo deba buscar la transformación religiosa de la humanidad no cristiana. $\mathrm{Mu}-$ cho más que eso, el cristianismo está ordenado a una misión que consiste -como dijo Cristo ante Pilatos (cf. Jn 18,37)- en dar testimonio de la verdad: "ésta es la actitud indefectible de la Iglesia: ser justamente testimonio de la verdad, no solamente frente a las demás religiones, sino en el seno de todas ellas" (19). La actitud cristiana, que reconoce la verdad de otras religiones aunque afirma su propia verdad definitiva, es una actitud testimonial o -según el significado de martýrion- martirial. El martirio cristiano no radica en dar la vida por una verdad, sino en el testimonio de la verdad por el que se da la vida. Mártir es alguien a quien se mata precisamente porque es mártir, testigo de la verdad, como se ve en Jesús, el mártir por excelencia. Por eso perder la vida es "consecutiva al testimonio de la verdad, y no formalmente constitutiva del martirio". La versión cristiana hacia las demás religiones es así testimonial, martirial, y por eso mismo busca la "salvación de las demás religiones" (20). Pero la busca no solamente con lo que dice, sino ante todo con lo que es, apelando a la libertad humana antes que a la

(1993), Reinhold, Der Absolutheitsanspruch des Christentums. Von der Aufklärung bis zur Pluralistischen Religionstheologie, Gütersloh, Gütersloher Verl.-Haus Mohn 1993, pp. 58-70), en el cual el concepto central es el de revelación (Offenbarung), y que conoce una versión eclesiocéntrica (desde Marción, Tertuliano, Cipriano y Agustín, hasta el reconocimiento dogmático de la infalibilidad papal en 1870) y otra versión cristocéntrica (desde Lutero hasta Barth). Sus dos principios son: (a1) la diferencia cualitativa entre el cristianismo y las otras religiones y verdades filosóficas o cosmovisivas, en el sentido de un enfrentamiento dualista entre uno y otras (verdadero-no verdadero, correcto-falso, vida-muerte, luz-oscuridad, salvación-reprobación). (a2) La única y exclusiva pretensión de validez del cristianismo implica al mismo tiempo la reprobación (Verwerfung) de lo no cristiano. B) El modelo de la superioridad jerárquica (vid. pp. 71-94) de Schleiermacher, Hegel, Troeltsch, Otto, Mensching y Pannenberg, cuyos dos principios son: (b1) la continuidad final entre el cristianismo y las otras religiones y verdades filosóficas y cosmovisivas, en el sentido de una equivalencia o igualdad o unidad principial (prinzipielle Gleichartigkeit $o$. Gleichheit o. Einheit) entre uno y otras. (b2) La posición de primacía (Vorrang) del cristianismo (que no niega por ello la validez de dichas religiones y verdades no cristianas) a través de la noción de una superioridad normativa, sea cuantitativa o cualitativa. C) El modelo de la dualidad inclusivista (vid. pp. 94-124), desde la doctrina del lógos spermatikós y la 'una religio in rituum varietate' del Cusano hasta Heiler, Panikkar, Ratschow, Althaus, Rahner, Schlette y Tillich, cuyos dos principios son: (c1) la dualidad: el cristianismo y las religiones están situados en una posición básicamente diferente; entre ellos no hay una línea de ascenso ininterrumpido y constante. Contra el modelo de la superioridad jerárquica, se dice que el rango superior no puede ser alcanzado con una prolongación, nuevo desarrollo o complementación de lo inferior, sino solamente a través de su superación (Aufhebung), conversión (Umkehr) o depuración (Läuterung). (c2) La inclusividad: contra el modelo dualista de la validez única y exclusiva, la diferencia principial no se conecta con ninguna exclusividad. El cristianismo y las religiones están subordinados (hingeordnet) de manera positiva e incluyente, en el sentido de dos niveles de altura distinta (übereinanderliegende Ebenen), uno más abajo, que es el elemental-universal, y otro más arriba, que es el específico, necesitando el más bajo de la elevación (Erhebung) hacia el más alto y estando dispuesto para eso (und ist daraufhin angelegt).

(18) Zubiri, Historia (n. 1), p. 341.

(19) Zubiri, Historia (n. 1), p. 342. Mientras no se diga lo contrario, las siguientes citas de Zubiri corresponden a la misma página.

(20) Por eso mismo, no hay que mantener una noción excluyente de martirio: "aquel que muere por la fidelidad absoluta a una posición de consciencia irrefragablemente compartida y poseída, es un mártir ante Dios, cualquiera que sea la confesión que le haya sacrificado": Historia (n. 1), p. 333. 
fuerza, y confiando siempre en el dinámico poder de Dios (dýnamis tô̂ theoû; cf. 1 Co 1, 23) (21).

El cristianismo, pues, es la verdad definitiva de todas las religiones. ¿En qué consiste esta verdad? ¿Cuál es la discontinuidad o peculiaridad que destaca al cristianismo como la religión definitivamente verdadera y que la eleva así de una manera inconfundible sobre las demás religiones y opciones fundamentales sin por ello negarles su propio valor de verdad?

\section{LA ESENCIA DEL CRISTIANISMO}

Zubiri es constante al respecto: la peculiaridad irreductible en cuya virtud el cristianismo no se puede colocar en una misma línea de desarrollo con las demás religiones consiste en la encarnación o divinización de la vía de la transcendencia, y en la consiguiente deificación o deiformación del hombre. Quizá si la mejor y más extensa justificación de esta tesis teológica es la que se halla en su antiguo estudio "El ser sobrenatural: Dios y la deificación en la teología paulina", redactado como "notas fragmentarias y casi telegráficas" (22) para impartir un par de cursos en 1934-1935 y 1937-1939. Dicha tesis resulta interesante porque está profusamente apoyada en presupuestos filosóficos, y aunque estos todavía no tengan la forma madura de Sobre la esencia e Inteligencia sentiente, en ocasiones la preludian. Bajo la apariencia de una reflexión en torno a la teología desarrollada en la carta paulina a los romanos tal como fue interpretada por la patrística griega, Zubiri expone allí los rasgos centrales del cristianismo conforme a los siguientes pasos: el ser de Dios como infinito éxtasis de amor, la procesión de Dios como íntima efusión trinitaria, la creación como externa efusión de Dios, la deificación como encarnación y la deificación como santificación:

"el ser de Dios, en su íntima realidad, es un amor efusivo, y su efusión tiene lugar en tres formas, metafísicamente diversas. Se efunde en su propia vida personal, se proyecta exteriormente creando las cosas, se da a sí mismo a la creación para asociarla a su propia vida personal en la deificación. Procesiones trinitarias, creación y deificación, no son sino los tres modos metafísicamente distintos de la efusión del ser divino entendido como amor. Tal fue la mente de los Padres griegos [...] La deificación [...] tiene dos momentos perfectamente distintos. En un primer sentido, Dios mismo hace de una naturaleza creada, el hombre, la naturaleza de su propio ser personal, metafísicamente considerado. Esta unidad metafísica, sobresustancial y personal, es la realidad de Cristo. A esta efusión deificante se la llama Encarnación. Pero -segundo momento- por medio de Cristo los demás hombres obtienen una participación de su vida personal en la vida personal de Dios: es la Santificación" (23).

(21) Zubiri, Historia (n. 1), pp. 343-344. Zubiri agrega, sin que podamos detenernos mayormente en ello, que la dinamicidad del poder de Dios es santificante, perenne y expectante (vid. Historia, $\mathrm{n}$. 1, pp. 344-346).

(22) Zubiri (n. 13), p. 456.

(23) Zubiri (n. 13), pp. 463 y 504. 
Veamos brevemente en qué consiste esta interpretación del cristianismo.

(a) El punto de partida de Zubiri radica en que el ser de Dios es infinito éxtasis de amor. En la visión de los Padres griegos, agápe es la palabra clave para definir el ser divino. Pero agápe no es tanto la virtud moral de una facultad especial, la voluntad, cuanto aquello que en último término es la estructura metafísica de la realidad en cuanto tal. Hay aquí toda una idea del ser, dice Zubiri. Para los Padres griegos, el ser es un principio dinámico, una actividad unificante y originaria. 'Es' significa

“[...] lo que efectivamente está siendo. En tal caso el ser es operación. Y cuanto más perfecto es algo, más honda y fecunda es su actividad operante. El ser, dice Dionisio Areopagita, es extático: cuanto más 'es', más se difunde, en uno u otro sentido [...] El ser es, pues, una especie de primaria y radical operación activa por la que las cosas son más que realidades, son algo que se realiza" (24).

Mientras más perfecto es un ente, más unitaria y activa es su realidad, y sus mismas dynámeis son la expresión de su ousía, la patencia de su íntima riqueza ontológica. Es decir, en los entes que se aproximan a la infinitud del ser hay algo cercano a la actividad pura, a una enérgeia perfecta que es el acto de su propio ser. Por esta razón, la causalidad es la excentricidad de esa radical actividad unitaria que es como el fondo mismo del ser. Esta unidad es la unidad de los entes consigo mismos (intimidad), con su progenitor (originación) y con todos los de su misma especie (comunicación). Y dado que la causalidad es sobre todo la proyección formal y la presencia ad extra de la causa en el efecto (25), la causalidad es bondad y, en este sentido, tanto la causa como el efecto son buenos (26). Esta bondad es una misma cosa junto con la unidad antes mencionada, y ambas en conjunto manifiestan la entidad en toda su profundidad. Tal manifestación profunda es justamente la verdad ontológica. La verdad es la esencia en último término inescrutable, pero siempre radical, unitaria y dinámica de los entes por sí mismos (y no por su referencia a otros). Como se ve, la metafísica de los Padres griegos es dinámica:

"en realidad, pues, el ser, aun finito, es actividad, y sus actos no consisten sino en volver a sí mismo: epísodis eís hautó, marcha hacia lo mismo, la llamaba ya Aristóteles" (27).

(24) Zubiri (n. 13), pp. 467-468.

(25) "El efecto no es simplemente algo recibido en un substratum, sino, si se me permite la expresión, la excitación, por parte de la causa, de la actividad del ser en el que va a producirse el efecto, para que la actividad de este produzca, y por tanto reproduzca, aquello que en una u otra forma estaba precontenido en la actividad de la causa" (n. 13, p. 472).

(26) "La esencia de la causalidad es bondad, decía Alejandro de Hales: en la causa, porque es su propia perfección interna; en la actividad causal, porque despliega su perfección; en el efecto, porque la reproduce" (n. 13, p. 473).

(27) Zubiri (n. 13), p. 476. 
La ousía es activa por sí misma, y por lo tanto lo son también sus potencias -que expresan la esencia- y sus actos -que expresan las potencias-. En unas y otros hay una patencia formal de la esencia. Unas y otros la acusan. La verdad y la bondad son denunciadas por potencias y actos; es la dóxa, en su doble función de revelación manifestativa (alétheia) y de proclamación pública (gloria). Por esto mismo es por lo que la dóxa es semejanza interna de la esencia, su expresión reluciente, su eikón:

"[...] tomado el contenido de la dóxa en sí mismo, resulta ser el cuadro explícito de las perfecciones de la esencia radical. Por esta relación puede llamársele semejanza de esta; pero no una semejanza como relación externa, sino una asimilación interna [...] A esta semejanza los griegos llamaron eikón, imagen. Por proceder de la esencia (ektýpoma) es ya una semejanza (homoíoma), y por dejar relucir en ella a la esencia es una verdad suya, nos la hace visible (ekphantoriké) y nos la muestra (deiktiké) [...] El ser eikonal nos revierte a la esencia de quien es semejante, y, por tanto, es la última expresión de la unidad del ser consigo mismo. No olvidemos la diferencia profunda de esta noción griega de eikón con la latina de imago. La imago es imagen porque se parece a lo imaginado; pero el eikón se parece a lo imaginado porque procede de él" (28).

Desde aquí hay que volver al ser de Dios. Para este retorno, es obligado dar un rodeo por el ser humano. En el hombre hay una diferencia entre naturaleza, 'lo que se es', y persona, 'el que se es'. Para los Padres griegos, la raíz del ser humano es la persona; el 'qué' natural tiene por principio al 'quién' personal:

"para los griegos y los victorinos lo que formalmente constituye la persona es una relación de origen (san Buenaventura lo repite textualmente); lo que constituye la naturaleza es algo en cierto modo abstracto y bruto, por muy individualizada que se la considere. Ricardo de San Víctor introdujo una terminología que no hizo fortuna, pero que es maravillosa. Llamó a la naturaleza sistencia; y la persona es el modo de tener naturaleza, su origen, el 'ex'. Y creó entonces la palabra existencia como designación unitaria del ser personal [...] La persona es alguien que es algo por ella tenido para ser: sistit pero ex. Este 'ex' expresa el grado supremo de unidad del ser, la unidad consigo mismo en intimidad personal. Aquí la unidad personal es el principio y la forma suprema de unificación: el modo de unificarse la naturaleza y sus actos en la intimidad de la persona" (29).

Esto es importante cuando se trata de Dios, que no puede concebirse sino personalmente. Así, que Dios sea amor significa que metafísicamente es el más activo y unitario de los seres, pura actividad subsistente, desbordante y extática

(28) Zubiri (n. 13), p. 476.

(29) Zubiri (n. 13), pp. 477-478. 
(30). Y como Dios es persona, su actividad efusiva es personal, lo que vale tanto de las procesiones trinitarias como de la creación y de la deificación. Las propiedades de Dios, de las que solo puede hablarse analógicamente (como siempre que se trata de Dios), son la expresión de la riqueza de su esencia y poseen carácter personal:

“esto es Dios para los griegos. Una pura acción personal, insondable; en la pureza de su acto va expresado ya el carácter de su persona. En Dios la naturaleza es tenida por identidad radical en la persona. Visto desde fuera, se manifiesta como éxtasis infinito, como fecundidad infinita; y por esto concebimos a Dios como amor. Su unidad metafísica es su éxtasis. Y en la pureza de su acto se expresa finalmente, también, la absoluta unificación de todos los atributos con su propio ser, en intimidad metafísica" (31).

(b) Con esto, Zubiri puede abordar la procesión de Dios como íntima efusión trinitaria. Sobre la base de la metafísica recién reseñada, los Padres griegos intentaron conceptuar las procesiones divinas, de las que por supuesto solo se tiene noticia por revelación. Esta metafísica encuentra aquí singular aplicación. Dios es visto desde cada una de las tres personas, en primer término desde la persona del Padre, siendo problema entonces cómo todas ellas constituyen un solo Dios:

“los griegos verán más bien cómo Dios al realizarse como persona se tripersonaliza, de tal suerte que la trinidad de personas es justamente la manera metafísica de tener una naturaleza idéntica; las personas no comienzan por oponerse, sino por implicarse y reclamarse en su respectiva distinción [...] Para los griegos cada persona no puede existir sino produciendo la otra, y del concurso de esta producción personal queda asegurada (si se me permite la expresión) la idéntica naturaleza de un solo Dios” (32).

Dios no recibe su naturaleza sino que la tiene eminentemente por sí mismo; por esto es por lo que su persona es infinita, e infinita también su fecundidad que -solo por revelación- sabemos que produce las procesiones personales. El amor infinito que es Dios es principio fecundo de personas, y gracias a esto su naturaleza es única e idéntica:

“es lo que se llamó la perikhóresis o circumincesión de las personas divinas. Cada persona no puede afirmar, en cierto modo, la plenitud infinita de su naturaleza, sino produciendo la otra [...] Si volvemos ahora a la definición de persona de Ricardo de San Víctor, fácilmente comprendemos, según nuestro modo humano, lo que significa la Trinidad. La razón formal de la personalidad

(30) "Por esto su ser, que es infinito, es infinitamente extático; tiende a comunicarse como fuente infinita (pegé), como fontanalis plenitudo". En nota Zubiri aclara: "me refiero, naturalmente, a la comunicabilidad. El hecho de su comunicación efectiva, en la creación, es libre, pero en la Trinidad misma es necesario" (n. 13, p. 480 n. 1).

(31) Zubiri (n. 13), p. 481. Esta determinación metafísica de Dios como amor efusivo y fecundo es algo que Zubiri nunca abandonará (vid. por ej. Sentimiento, n. 14, pp. 46, 190-191, 384-385 y 390).

(32) Zubiri (n. 13), pp. 482-483. 
está en el 'ex', en la relación de origen. Los tres modos del 'ex' son las tres personas cuya mutua implicación asegura su idéntica sistencia natural” (33).

Así, los Padres griegos enfatizan la innascibilidad del Padre en cuanto principio fecundo, la generación del Hijo cuyo término es una segunda persona que tiene que tener idéntica naturaleza que el Padre, y la actividad manifestativa del Espíritu Santo que ratifica que el Hijo es la expresión del Padre. De ahí que el Hijo y el Espíritu sean eikónes, imágenes del Padre, justamente porque proceden de él. Este esquema afecta a la creación y a la deificación, como ahora veremos.

(c) La creación es la externa efusión de Dios. En la mente de los Padres griegos, dice Zubiri, la creación es la difusión de la actividad divina a través de la posición de la alteridad (34). Esto es algo toto caelo distinto de un panteísmo y de un emanatismo: la misma agápe divina en su vida trinitaria es fecunda, pero ad extra. Es, dice Zubiri, la teoría del vestigium Trinitatis:

"la creación es la Trinidad actuando causalmente ad extra. Tal es la idea griega [...] El Espíritu Santo realiza el imperio del Padre haciendo que haya cosas, y que estas sean lo que está en el Hijo. La creación, pues, como acto absoluto de Dios, es una voz de Dios en la nada. El logos tiene un sujeto: la nada; y un predicado: las ideas divinas. El resultado es claro: la nada se transforma (si se permite la expresión) en 'alguien' (sujeto), y las ideas se proyectan en este alguien haciendo de él un 'algo' (predicado). De esta suerte queda determinada la estructura ontológica de la creación: el ente finito es ante todo una dualidad entre el que es y lo que es. Como, sin embargo, todo ser es uno, la entidad (ontótes la llamaba Alejandro de Afrodisia) del ser finito es la unificación entre el que es y lo que es. En eso consiste el esfuerzo activo del ser como operación: el esfuerzo por ser el que se es [...] Entonces se explica cómo, sin mengua de la distinción entre Dios y las criaturas, todo cuanto hay en estas de ser positivo se deba a la presencia de Dios en ellas. Si tratándose de la causalidad finita la acción del agente es recibida en el paciente, tratándose del acto creador el paciente y su paciencia no existen sino por su presencia en el agente. Somos, nos movemos y vivimos en Él, dirá San Pablo [...] La finitud es la unidad tensa en una dualidad. No se es sí mismo sino desde y en una alteridad constitutiva; al ser finito le compete ser lo 'mismo' y lo 'otro': es la mismidad en la alteridad [...] Para los griegos, la creación es un vestigio de la Trinidad. Las cosas ejercitan su ser por la operación causal del Espíritu Santo; este las lleva a realizar su imagen ejemplar que está en el Hijo, y a unirse a la fuente del ser que está en el Padre, del cual recibieron, por el Hijo y en el Espíritu Santo, su propia realidad. Lo mismo tratándose de cada cosa que tratándose del cosmos [...]" (35).

(33) Zubiri (n. 13), pp. 486 y 492.

(34) “[...] La creación es una producción de lo 'otro', pero como difusión de sí 'mismo'. Y por tanto la creación, a la vez que produce las cosas distintas de Dios, las mantiene en unidad ontológica con Él mediante la efusión" (n. 13, p. 493).

(35) Zubiri (n. 13), pp. 495-497 y 503. Nótense las semejanzas con el artículo "En torno al problema de Dios", que también se refiere a lo que 'hace que haya' y cita la fórmula paulina. 
De esto se siguen dos consecuencias: una es la existencia de una jerarquía entitativa en la creación, y la otra es la unidad cósmica de las cosas creadas. En ambos casos los Padres griegos destacan el puesto del ser humano, que por ser persona o espíritu (bien que finitamente), es imagen y semejanza de su Creador y, en cuanto tal, transciende el tiempo y el espacio:

"[el hombre] tiene un espíritu (pnê̂ma), que abarca la totalidad de los momentos del tiempo, pero originariamente: el tiempo no es sino el despliegue de esa superior unidad transtemporal. Por esto el espíritu es a su modo eterno. Es lo que permanece en el hombre, y por tanto su único verdadero ser. Es él, entre todas las criaturas, aquella que más se asemeja a Dios, su predilecta criatura, eikón, imagen suya. Esta imagen es el fondo del ser humano, su bien y su principio [...] En el espíritu personal se manifiesta por excelencia el carácter originariamente unitivo del amor: replegado sobre sí mismo, el espíritu está en la eternidad atraído por Dios. Esa voz en la nada que es el acto creador, esa 'llamada' al ser, es en el caso del espíritu algo especial: no es una simple llamada, es una 'vocación'. Aquí lo llamado no solo 'es llamado', sino que 'consiste en ser llamado'; de suerte que su ser pende de su 'vocación divina'. El espíritu no solo tiene destinación, y no solo tiene vocación, sino que es formal y constitutivamente un ente vocacional. Este tender, mejor dicho, este depender, es el destino: Dios, como destino del espíritu, no es algo extrínseco a él, sino que se halla inscrito en el sentido mismo de su ser" (36).

El hombre es, por esto mismo, un microcosmos, el rey de la creación. Por el amor personal del que proviene y en que también consiste (claro que a su manera creada), está llamado a constituir un ámbito donde todos los seres humanos puedan aproximarse, vertirse unos a otros personalmente y ser prójimos (37).

(d) Pues bien: por una parte, la deificación que anuncia el cristianismo es sinónimo de la encarnación. Además de la creación, Dios se difunde de una manera completamente excepcional: dándose a sí mismo -personalmente- a una naturaleza humana. Es el misterio de la encarnación del Hijo de Dios en Jesús de Nazaret:

"el Hijo, como naturaleza divina, no puede comunicar sustancialmente con nada. Su nota personal -aquí está el misterio- es aquello de quien es lo que hay en una naturaleza humana singular. Visto desde Dios: la persona del Hijo

(36) Zubiri (n. 13), pp. 500-501. Nótense aquí la influencia heideggeriana (hay un tiempo originario que se despliega por éxtasis) y la presencia predemostrativa, aunque perfectamente intelectiva, de Dios en el seno la existencia humana.

(37) Zubiri comenta, en particular, que si el cosmos es el escenario de la actividad humana, las cosas se presentan en este teatro "[...] como dificultades o facilidades para la realización de la persona. A esto es a lo que más propiamente todavía suele llamar muchas veces el Nuevo Testamento cosmos. Es, si se quiere, el sistema de posibilidades que las cosas ofrecen por la situación concreta en que el hombre se halla" (n. 13, p. 502). Es notoria aquí la influencia de Ortega y de Heidegger, una influencia que declinará en la madurez de Zubiri, cuando este autor diga que con antelación a la funcionalidad de las cosas como posibilidades existenciales aparece la nuda realidad de ellas: es, por supuesto, la tesis de la prioridad de la realidad respecto del sentido. 
'realiza' su personalidad divina en una naturaleza finita y singular, en el sentido de que se mantiene idénticamente como Dios en el sujeto de quien es suya aquella naturaleza humana [...] Tratándose de Cristo, la persona divina tiene esta naturaleza singular humana, porque el Hijo la 'toma' activamente para sí. Esta relación de aprehensión es lo que se ha llamado asumpción” (38).

En Jesús, que era un hombre cualquiera, reside la plenitud de Dios (pléroma). Y por él, para él y en él -como compendio y cabeza- todas las cosas han de ser recapituladas (anakephalaiósasthai). Por esto es por lo que Cristo es primogénito de la creación entera y esta aguarda anhelante su futura transfiguración, cuando Dios sea todo en todos.

(e) Por otra parte, la deificación equivale a la santificación. Es la segunda forma de deificación: en Cristo, la vida humana es asociada a la vida personal de Dios. Esto es la santificación: la participación real, aunque puramente gratuita, de la existencia humana en la Trinidad. Por una decisión amorosa libérrima, el hombre recibe la naturaleza sobrenatural de Dios mismo:

"mientras Dios ha deificado a Cristo dándole su propio ser personal divino, deifica a los demás hombres comunicándoles su vida, que deposita en ellos una impronta de la naturaleza divina: es lo que la gracia tiene de 'ser'. Como esta impronta procede de Dios mismo, por vía de impresión y de expresión formal, es una semejanza con la naturaleza divina, y, por tanto, al recibir nosotros una naturaleza deiforme, somos realmente hijos de Dios. La deificación del hombre es real, pero, si se quiere, accidental: es algo añadido al ser humano, pero nada constitutivo suyo: es lo que justifica el nombre de kháris, gracia [...] Por esto conviene disipar la falsa imagen que la palabra 'sobrenatural' puede suscitar en las mentes. Parece que se trata de una superposición o estratificación de dos entidades. Esto es falso. La palabra 'sobre', hypér, indica tan solo que su principio es transcendente y gratuito. Pero no significa que la gracia sea una especie de ducha [...] Así como en la Encarnación la naturaleza humana no queda simplemente yuxtapuesta a la divina, sino que, asumida por la personalidad del Hijo, queda inmersa en la divina, análogamente la gracia absorbe, por así decirlo, al hombre entero en una unidad suprema y transcendente. De ahí el grave error que consiste en confundir la santidad con la perfección moral" (39).

Zubiri distingue, claro, con la tradición, la gracia increada (la inhabitación trinitaria misma en el alma del justo) de la gracia creada (la nueva héxis, el nuevo habitus que dicha inhabitación imprime en el alma humana). De ahí que la inhabitación de la Trinidad sea una regeneración (palingenesía), una renovación (anakaíno-

(38) Zubiri (n. 13), p. 512.

(39) Zubiri (n. 13), pp. 519 y 528-529. Conviene añadir que, a propósito del sobrenatural, Zubiri intenta definir el significado específicamente cristiano de religión: "la esencia de la vida sobrenatural es este diálogo cultual, sacrificial, del hombre con Dios por su unión con Cristo. Es esencialmente religión" (n. 13, p. 538). 
sis) que transforma la vida y el ser del hombre -individual y socialmente- otorgándole una segunda naturaleza, una naturaleza deiforme, que es una cualidad divina de la que el hombre por sí mismo - con sus solas fuerzas- carece (40). En virtud de esto, el hombre es no solo imagen (eikón) sino además y sobre todo semejanza (homoíosis) de Dios:

"hay que ver en los griegos no la inhabitación trinitaria desde la gracia, sino la gracia desde la inhabitación trinitaria. Así como en la procesión de las personas divinas se logra (por así decirlo) el acto puro de la única naturaleza divina, así también en el justo, según los griegos, la gracia es el precipitado de la vida divina, produciendo por presencia formal nuestra completa asimilación a Dios" (41).

Se imprime en el fondo abismal del alma -Zubiri utiliza esta fórmula de la mística medieval- la imagen del Hijo y, así, el ser humano se unifica con el Padre por la fe y en el amor. De este modo, participamos de la santidad de Dios, el único Santo: la gracia es santificante y nuestro ser es consecuente y metafísicamente santificado (42). Así, pues, el misterio (mystérion, sacramentum) de la voluntad del Padre es la raíz no solo de la encarnación sino también de la santificación. Y la santificación es somática, porque la presencia de Cristo en el hombre es somática, tal como su sacrificio redentor fue corpóreo. De ahí también que la Iglesia sea el sacramento, el cuerpo místico de Cristo en la historia, y que este sea a su vez la cabeza (kephalé) unificadora y articuladora de este cuerpo eclesial y de la entera humanidad (43). En la historia, por fin, está ya presente y operante el amor deificador, pero todavía no de manera plena sino solamente en germen: la vida eterna está actuando ya ahora incoativamente, pero la definitiva consumación escatológica -la plenitud de los tiempos- está aún por cumplirse (44).

Me he demorado en la exposición no solo porque Zubiri será fiel a esta teología fundamental hasta el final, sino también porque toda ella tiene numerosos presupuestos filosóficos. La evolución de Zubiri hará que esa filosofía presupuesta, lejos de desaparecer, se transforme y madure. Los cursos de los años 60 y 70 sobre el proble-

(40) Zubiri cita y hace suyas estas fórmulas: “san Ireneo emplea la expresión 'hacerse Dios' (Deum fieri). 'Dios, dice san Atanasio, se hizo hombre para que el hombre se hiciera Dios.' Y san Cirilo de Alejandría expresa esta misma idea: '[...] hasta que se forme Cristo en vosotros'. Y se forma Cristo en nosotros por el Espíritu Santo, que nos reviste con una cierta forma divina (theían tinà morphósin)" (n. 13, p. 522). Estas expresiones, y la idea subyacente, acompañan a Zubiri hasta su madurez. Además, Zubiri utiliza la metáfora de la luz y del color, del foco luminoso y de la cosa iluminada (vid. n. 13, pp. 524 y 528) para referirse a la presencia difusiva -como el tipo en la copia, el sello en la impronta- y sobrenaturalizante de la Trinidad en el hombre, una metáfora ya presente en "Hegel y el problema metafísico" (vid. n. 13, p. 286) y que reaparece en Sobre la esencia (Madrid, Sociedad de Estudios y Publicaciones 1962), pp. 447-448, y en el curso sobre el problema teologal del hombre (Cristianismo, n. 1, p. 94).

(41) Zubiri (n. 13), p. 526

(42) Por eso el pecado tiene, más que una cualidad moral, una dimensión ontológica y cósmica (vid. n. 13 , pp. 527-528).

(43) Vid. Zubiri (n. 13), pp. 529-541. Todo esto apunta al sentido radical de sacramento, del cual participan los siete sacramentos católicos.

(44) Vid. Zubiri (n. 13), pp. 541-542 
ma de Dios así lo demuestran. El cristianismo, dice entonces, es la religión de la encarnación y la deiformación (45). Es la religión para la que "no solamente se accede a Dios, sino que se accede divinamente a Dios" (46). Por un lado, la deiformidad significa que Jesús mismo es hombre y es Dios: “[...] Cristo no solamente transmite la palabra de Dios, sino que es en su propia realidad la Palabra misma de Dios" (47). Por el otro, debido a esta encarnación de Dios la deiformidad afecta al ser humano:

"si Cristo es Dios, llegar a Dios por Cristo significa que en esa entrega el hombre va a llegar a conformarse como es Cristo. Ahora bien, Cristo es Dios. Y precisamente por eso, la deiformidad del hombre es justamente el término positivo por el que está justificada teologal y metafísicamente la paternidad divina, y no por un mero sentimiento" (48).

Zubiri vuelve a tocar la cuestión del sobrenatural. Toda la creación, que es la posición de la alteridad de lo real sin alteración de la realidad plenaria que la ejecuta, es plasmación ad extra de la vida trinitaria, y en el caso del hombre es, más que una elevación sobrenatural, un descenso de la vida trinitaria a la finitud humana (49). Zubiri, por ello, se aleja tanto de la teoría 'psicológica' de la Trinidad de Agustín como de la dialéctica trinitaria concebida por Hegel:

"no se trata [...] de una imagen de la Trinidad, porque no se trata de buscar en la realidad humana algo que nos recuerde o nos refiera a la realidad divina, sino justamente al revés: se trata de partir de la Trinidad como fundamento que hace posible las estructuras del hombre [...] No se trata, como diría Hegel, de ver cómo el hombre en última instancia es una finitud que se va a hacer Dios dialécticamente, sino justamente al revés: de abrirnos las puertas a lo que nos va a enseñar más tarde la revelación, a saber: cómo Dios se ha hecho hombre” (50).

La idea del sobrenatural como elevación es para Zubiri una mala helenización del cristianismo. Sea de ello lo que fuere, el descenso trinitario hace del hombre un hijo de Dios. La filiación adoptiva pero real del hombre es deiformante: por Jesús,

(45) Vid. Zubiri, El hombre y Dios (Madrid, Alianza 1984), pp. 319-323, 330-331, 356-362 y 380-381; Historia (n. 1), pp. 329-330 y 335; Cristianismo (n. 1), pp. 65-77 y 233-396. Aunque todavía sigue usando con cierto indiscernimiento las expresiones deiformidad y deificación (vid. Cristianismo, n. 1, pp. 222 y 442), alguna vez Zubiri cree preferible prescindir de la última: “[...] la creación y los entes creados tienen una condición que llamo deiformidad. No deificación, porque eso envuelve la idea de hacer dioses. No es esto, sino que en sí mismos, en tanto que hechos y creados, son deiformes" (Cristianismo, n. 1, p. 313). En otro lugar, Zubiri piensa que no hay que prescindir de la deificación sino solo reservarla para lo que ocurre con el justo: "es lo que a mi modo de ver ha de entenderse en la expresión paulina de mórphosis y que, mejor que deificación, yo llamaré deiformidad, porque [...] solo el justo está deificado, pero todo hombre, aun el condenado, es deiforme" (Cristianismo, n. 1, p. 37). Estas precisiones vacilantes son en todo caso puramente terminológicas, y no parece que lo que con ellas quiere decirse ofrezca mayores problemas.

(46) Zubiri, Historia (n. 1), pp. 329-330.

(47) Zubiri, Historia (n. 1), p. 250.

(48) Zubiri, Historia (n. 1), p. 251.

(49) Vid. Zubiri, Cristianismo (n. 1), pp. 154 y 230.

(50) Zubiri, Cristianismo (n. 1), pp. 213-214. 
el hombre es hijo de Dios (51). Pero además, el hombre es como Dios a través de la fe. La fe cristiana es la entrega personal a Jesús a través de la cual se adquiere su misma corporeidad: el cristiano es el que se ha incorporado a Jesús a través de la fe haciendo suya su presencia real y su consistencia interna. Así, el hombre accede a Dios por Jesús: "la historia entera de la humanidad constituye en una o en otra forma una experiencia de acceso a Dios a través de Cristo" (52). La acción de Jesús de dar acceso a Dios es histórica y transcurre históricamente. La fe es la entrega personal e histórica a través de la cual se verifica la incorporación humana a Jesús. Desde el punto de vista de la deiformación humana, hay que decir que "Cristo nos sumerge en la realidad misma del Padre" (53). Y desde el punto de vista de la encarnación divina, debe añadirse que, "como acceso a Dios, Cristo es Dios hecho historia" (54). Sumergido Dios en la historia humana mediante la encarnación del Hijo, la fe incorpora al hombre a Jesús y lo sumerge en Dios históricamente: "se trata de una fe en un Dios hominizado para un hombre deiformado" (55). La deiformidad no es un atributo humano más, sino el constitutivo formal del hombre:

"el hombre es la proyección ad extra de la vida misma de Dios. Ser hombre es una manera finita de ser Dios: es ser Dios humanamente. Lo que llamamos 'naturaleza humana' no es sino este momento de finitud" (56).

Por la deiformación, no es solo el hombre el que se incorpora a Jesús y se sumerge en Dios, sino que es Dios mismo el que se incorpora al hombre. La incorporación vital de Dios al hombre hace de este un ser deiforme. Y la incorporación personal de Dios a un hombre es lo que constituye la realidad humana y divina de Jesús:

\footnotetext{
"en su virtud, toda deiformidad se halla fundada en Cristo, toda vida personal es una opción respecto de Cristo, y la historia entera es un proceso hacia Cristo y desde Cristo: es el cristianismo. El cristianismo no es sino la índole 'crística' de la deiformidad. El cristianismo es la vida humana como experiencia teologal de la deiformidad. Es la experiencia que enseña cómo el hombre se puede hacer Dios viendo cómo Dios se ha hecho hombre" (57).
}

Esta forma de entender el cristianismo tiene una precisa consecuencia. Y es que entonces la religión cristiana no se dirige primariamente a la fractura moral del hombre, a su condición de pecador necesitado de rescate. El hombre tiene, por la gracia, forma divina. Y el cristianismo se dirige ante todo al hombre en tanto que deiforme. Según Zubiri, la salvación se basa en la posibilidad humana de separarse de Jesús, y por ende de Dios mismo. Pero "en sí y formalmente", el cristianismo

(51) Vid. Zubiri, Cristianismo (n. 1), pp. 73-74.

(52) Zubiri, Historia (n. 1), p. 255.

(53) Zubiri, Historia (n. 1), p. 256.

(54) Zubiri, Historia (n. 1), p. 256.

(55) Zubiri, Historia (n. 1), p. 257.

(56) Zubiri, Cristianismo (n. 1), p. 616; vid. también 214.

(57) Zubiri, Cristianismo (n. 1), pp. 616-617. 
anuncia no la salvación sino la esencial deiformación humana (58). Antes que una religión de salvación, es religión de deiformación. Debe decirse que el cristianismo es religión de salvación porque es religión de deiformación:

"[...] la salvación sería no el momento constitutivo del cristianismo sino un momento consecutivo a él. En el símbolo de Nicea se nos dice que el Verbo bajó del cielo 'por nosotros los hombres y por nuestra salvación' (DS 125). Podría pensarse entonces que el 'por nosotros los hombres' es algo 'anterior' al 'por nuestra salvación'. El cristianismo es formalmente, en expresión paulina, una mórphosis (cf. Rm 2, 20), una conformación divina del hombre entero; en mi interpretación, una deiformidad. El cristianismo es salvación solo porque es deiformación. Es uno de los puntos en que me parece insuficiente la teología actual. El cristianismo se dirige primariamente al ser entero del hombre y no a su caída en pecado y menos aún a las fallas de su vida. El cristianismo no es la argamasa que remienda las fisuras de la vida. El cristianismo, a mi modo de ver, dirá al hombre actual que su vida es lo que es precisamente porque el ser del hombre es deiforme; y lo es no en sus fracasos sino primaria y principalmente en sus propios logros. Y, entonces, una cosa es clara. El punto de coincidencia entre el hombre actual y el cristianismo no es la indigencia de la vida sino su plenitud. Cuando la vida se asienta más sobre sí misma, es entonces cuando formalmente está siendo más en Dios y con Dios. La deiformación cristiana es el fundamento positivo de una vida plenariamente asentada sobre sí misma" (59).

(58) Vid. Zubiri, Cristianismo (n. 1), p. 617.

(59) Zubiri, Cristianismo (n. 1), pp. 18-19; vid. Dios (n. 45), pp. 160-161 y 381. Con todo, más de alguna vez Zubiri parece no respetar esta prioridad de la deiformación sobre la salvación. En el curso sobre la voluntad se refiere a la encarnación y la redención como iniciativas divinas activas a priori. A propósito del problema de "si efectivamente la razón formal de la encarnación fue o no el pecado de Adán” (Sentimiento, n. 14, p. 188), dice que la encarnación supone la realidad de ese pecado original. Y en cuanto a la redención, añade que es una iniciativa divina que se realiza, "hagan lo que hagan las libertades humanas" (Sentimiento, n. 14, p. 189). Otras tantas consideraciones agrega en el curso sobre el problema del mal. El origen del mal está, para el cristianismo, en un acto malicioso del hombre, pero realizado por instigación maligna del demonio. Dios permite esa inspiración diabólica porque ha decidido eternalmente la encarnación y la redención. Dios quiere para la humanidad un bien transcendente que supera a todo mal. Ese bien es Dios mismo, "como culmen no solo de mi sustantividad humana, sino como participación real y efectiva de mi sustantividad en la condición misma de ese Dios que se ha incorporado en la realidad humana" (Sentimiento, n. 14, p. 313). Es el hecho inaudito de la deiformación humana. Por esto es por lo que el bien ya no es solo agathón sino kháris, y el mal no es solo kakía sino hamartía (vid. Sentimiento, n. 14, pp. 313-314). La oscilación entre el bien y el mal es ahora un vaivén entre la gracia y el pecado. La encarnación hace que este vaivén esté desde ya desequilibrado a favor de la gracia y del bien, pues el príncipe de este mundo ya está juzgado (cf. Jn 16, 11). Biográficamente, esto significa que Dios "no solamente permite el mal sino que ayuda al hombre a salir de él" (Sentimiento, n. 14, p. 314). Y lo hace a través de la Iglesia, que es "el cuerpo donde él ha depositado la gracia" (Sentimiento, n. 14, p. 314). Existe la posibilidad de condenarse, si la aversión a Dios y la correspondiente búsqueda maliciosa del propio mal ha sido proseguida hasta la muerte. La condena eterna, empero, no es una pena que tenga a Dios por autor: "la pena del condenado no es una pena impuesta por Dios, sino una pena querida por el propio condenado [...] Es que el condenado en el infierno quiere real, efectiva y positivamente la situación de pena en que se halla" (Sentimiento, n. 14, p. 315; vid. también 316). Pero existe la posibilidad de salvarse, que no es fruto de un merecimiento. Hay una cierta congruencia entre la vida y el destino eterno, 
A partir de estas intuiciones centrales, Zubiri esboza toda una teología fundamental. Por eso insinúa su punto de vista respecto de los tratados clásicos de la teología dogmática o sistemática, refiriéndose sucesivamente a Dios en Cristo, a la Trinidad y la encarnación, y a la creación y la Iglesia.

Ha de añadirse, por lo que acabamos de ver, que Zubiri tendría que haber sido muy crítico con la idea del cristianismo que se forjó Heidegger. Heidegger conoce bien la tradición cristiana, al menos por lo que toca a algunos de sus filones más significativos. Su juicio es duro tratándose de la repercusión cultural y filosófica del cristianismo histórico, pero es matizada e incluso admirativa cuando se refiere al cristianismo originario testimoniado en los escritos neotestamentarios. De ahí la renuencia de Heidegger a dar base metafísica a la fe cristiana. Bien puede afirmarse que Heidegger caracteriza al cristianismo originario siguiendo la estela de Agustín y Eckhart, Lutero y Pascal, Kierkegaard y Bultmann: el cristianismo sería el acontecimiento salvador de la cruz y la resurrección de Jesucristo apropiable por medio de la fe, de un salto, una decisión que transforma la orientación de toda la existencia. Jesús es el Hijo de Dios justamente porque salva al hombre. Zubiri, en cambio, pone otro énfasis. No es solo que estime posible elaborar metafísicamente una concepción coherente de la divinidad; también puede y debe darse base metafísica a la revelación cristiana, claro que superando (siempre que sea necesario) el repertorio de conceptos de la clásica filosofía griega, como insinúan -según vimos- los propios Padres griegos. De esta forma, Zubiri también puede entender que el cristianismo es un acontecimiento, pero ante todo el acontecimiento deiformante de la vida, muerte y resurrección de Jesucristo que -por medio de la fe y los sacramentos- transforma radical y enteramente al ser humano. Si Dios salva, es porque se ha hecho hombre y porque así ha asociado al hombre a su vida divina. No todo son diferencias, eso sí. Como Heidegger, Zubiri también estudió sistemáticamente teología y llegó a conocer bastante bien la historia intelectual del cristianismo. Esta interna convivencia entre teología y filosofía hizo que Zubiri pensara que una y otra son existencialmente compatibles. Por esto el juicio de Zubiri respecto de la función cultural y filosófica del cristianismo, aunque incluya una dimensión crítica, en todo caso posee mayores matices que el de Heidegger.

El cristianismo, en suma, es la verdad definitiva y suprema de todas las religiones, y lo es justamente por constituir el acceso divino a Dios, la divinización de la vía teísta, la religión que anuncia la salvación solo porque previamente proclama la deiformación. ¿De dónde brotan estas afirmaciones? ¿Cómo se saben tales cosas? ¿Cuál es la estructura intelectiva de la teología cristiana?

dice Zubiri, pero esta congruencia no equivale a merecimiento moral ninguno: "es una congruencia libremente querida y determinada por Dios" (Sentimiento, n. 14, p. 317). La gracia divina salvadora es siempre gratia Christi y gratia Ecclesiae: "cuando Dios justifica al que está de buena fe y no pertenece a la Iglesia, le da una gracia no fuera de la Iglesia, sino fuera de la vía sacramental" (Sentimiento, n. 14, p. 317). En este sentido, es cierto que fuera de la Iglesia no hay salvación. Pero es que también puede salvarse el que no pertenece a la comunidad cristiana, quien entonces se salva por una gracia "que está depositada y que arranca del seno de la Iglesia" (Sentimiento, n. 14, p. 318). 


\section{EL LÓGOS CRISTIANO}

Sabemos que la teología es una empresa de la razón. El lógos de la teología al que se refiere Zubiri no es el "logos" campal, sino la intelección principial y canónica, la búsqueda del fundamento esencial con independencia de la aprehensión. En una palabra, es razón. Claro que el lógos teológico es un conocimiento confesionalmente orientado, puesto que se asienta en la revelación cristiana. Zubiri no puede menos que reconocer que ante los tres grandes monoteísmos religiosos "solo puede decidirse por una opción interna de la fe" (60). El cristianismo no escapa a ello; es una opción de fe, una opción razonable pero que excede los límites de la razón humana (61). Despunta aquí con claridad una tesis cara a la mentalidad teológica: que lo que la razón puede conquistar por sí sola no se identifica con lo que la razón puede recibir. Tan es así que no se exagera si se dice que la razón teológica se funda en la realidad de Jesús en tanto que Verbo encarnado:

"la revelación, en efecto, no es solo, ni en primera línea, revelación de una doctrina, sino incorporación de Dios mismo a la realidad humana, una incorporación que culmina en la Encarnación. Y, recíprocamente, es Cristo quien como Verbo encarnado en un hombre físicamente real, nos revela con su vida entera (enseñanzas y obras) a Dios mismo" (62).

La deiformación culmina efectivamente en la encarnación, y por ello el lógos cristiano tiene como primer sentido al Lógos hecho hombre, a Jesucristo. Jesús revela al Padre, es el revelador gracias al cual se conoce la verdad de Dios (cf. Rm 2, 20). Jesús es entonces el Lógos revelante mismo: "como personalmente existente en Cristo y como conformador del conocimiento y de la verdad en el hombre, el lógos no es un saber teológico, es decir, un saber acerca de la revelación, sino que es la revelación misma" (63). La accesible manifestación de Dios se vuelve ahora revelación, donación personal de Dios mismo, y justo esta revelación de Dios en Jesús es el Lógos del que se nutre toda teología cristiana (64).

Por eso la teología es el lógos derivado del Lógos revelante y fundado en él, y es así un lógos del theós como saber humano acerca de Dios. En este otro sentido, el lógos de la teología recae en la realidad revelada sin identificarse con ella. Es la mentalidad que marcha direccionalmente en pos de la realidad de Dios revelada para el ser humano, y que no se acantona ni en el polo divino (que eso sería especulación vacía) ni en el humano (sería pragmatismo ciego) de la revelación. Zubiri piensa con Buenaventura que la teología es itinerarium mentis in Deum. Si Dios está siempre accedido, lo quiera o sepa el hombre o no, el Dios cristiano está siempre ya revelado en Jesús:

(60) Zubiri, Historia (n. 1), p. 146.

(61) Vid. por ej. Zubiri, Cristianismo (n. 1), pp. 456 y 486.

(62) Zubiri, "Prólogo", en González, Misterio trinitario y existencia humana (Madrid, Rialp 1966), p. xii.

(63) Zubiri, Cristianismo (n. 1), p. 21.

(64) Vid. Zubiri, Cristianismo (n. 1), pp. 455-457. 
"es ciertamente un movimiento de la mente hacia un Dios revelador, pero hacia un Dios que está ya dado al hombre, el cual se halla arrastrado por Él en ese acto o estado que es la fe. Entonces el itinerario no es tanto un camino hacia Dios sino un camino en Dios hacia su interna desvelación e inteligibilidad. Más que la marcha del hombre hacia Dios, es el trazado de la penetración de Dios en la mente humana; un esfuerzo activo de la mente para que se ilumine cada vez más un Dios ya abierto a ella" (65).

Este es, propiamente hablando, el lógos teológico. Sus configuraciones históricas han sido al menos tres, según Zubiri. Hay, primero, un lógos kerygmático o meramente predicador, que es la proclamación, la propagación, incluso la propaganda del cristianismo. Luego, hay un lógos ostensivo o epideíctico, que ya intenta penetrar en el ser de las cosas a la luz de la revelación y, a la vez, en la revelación gracias al ser de las cosas. Es un lógos más complejo y ambicioso, que pretende mostrar la unidad de la revelación, la analogía de la fe (cf. Rm 12, 6), el cuerpo de la verdad (sôma tês aletheías, como dice Ireneo). Por fin, el lógos teológico se vuelve científico o apodíctico cuando ya no solo quiere mostrar sino demostrar conceptivamente la necesaria e interna articulación sistemática de la fe cristiana. Bastará con decir que, para Zubiri, pueden reconocerse en la constitución de esta ciencia teológica tres grandes etapas: especulativa, histórica y bíblica, dominadas bien por los conceptos de la metafísica griega (es lo que ocurre en autores como Orígenes, Agustín, Anselmo y Tomás de Aquino), bien por la historicidad de las tradiciones y los dogmas (lógos cuyo creador es Petavio), o bien por la exégesis y las ciencias hermenéuticas que permiten detectar e interpretar las categorías propias del texto bíblico (cuyo gran valedor en el campo católico es Lagrange) (66). Estas tres direcciones de la ciencia teológica no solo se han ido constituyendo a lo largo del tiempo sino que representan momentos constitutivos e indispensables de todo quehacer teológico:

"las tres teologías no son las tres ciencias en que se divide la teología, sino que son los momentos de un movimiento intelectual único, constituyen algo así como la dialéctica de un solo lógos científico. La teología científica es, pues, algo 'uno' que ha de abarcar, de un modo intrínseco y formal, una exégesis, una historia y una especulación” (67).

La teología es la razón intentando aclararse exegética, histórica y especulativamente el misterio de Dios, y de Dios en tanto que se ha hecho hombre. Es claro que para eso el saber teológico ha de recurrir a sus diversas tradiciones internas, así como a una multitud de saberes científicos. Zubiri, en efecto, pone énfasis en la pluralidad de tradiciones que se pueden encontrar al interior del cristianismo. Así se aprecia en "El ser sobrenatural: Dios y la deificación en la teología paulina", en el

(65) Zubiri, Prólogo (n. 62), p. xii.

(66) Vid. Zubiri, Cristianismo (n. 1), pp. 20-27, y Sobre el problema de la filosofía y otros escritos (1932-1944) (Madrid, Alianza 2002), pp. 285-290.

(67) Zubiri, Cristianismo (n. 1), p. 31. 
que Zubiri adopta un preciso método teológico, a la zaga de san Pablo y de los Padres griegos. En esta perspectiva, dice, la teología es una noticia de la real deificación del hombre y del universo que ha acontecido en el cristianismo, y segundo, es una expresión de esta noticia en un lógos: un lógos acerca de Dios y -a una con ello- un lógos desde Dios. De acuerdo a la teología griega, el ser humano es considerado como un trozo de la creación universal y, por esto mismo, el pecado es sobre todo una mancha en la creación. Según la teología latina, en cambio, el hombre es más bien una intimidad, y el pecado, una volición perversa. De ahí otras tantas diferencias. El amor es el principio metafísico de las cosas creadas, más que el movimiento aspiracional de una voluntad. La felicidad es consecutiva a la gracia deificante, y no al revés. Por estas y otras razones, dice Zubiri, la teología griega es muy apta para seguir la marcha de la teología neotestamentaria (68). La conclusión de estas observaciones es que la teología no debe empobrecerse recurriendo a una sola de sus tradiciones intelectuales, pues tiene ante sí una diversidad de posibles rutas, todas ellas racionales y fecundas:

"[...] la teología tiene en la Iglesia no uno sino muchos cauces. Ahora bien; la perfección lógica a que en Occidente llegaron algunos sistemas de teología, ha sido en buena parte responsable del olvido triste en que este sencillo hecho ha caído. Ya en el Occidente latino es indiscutible la diversidad de teologías, no solo en puntos y problemas aislados, sino hasta en sus concepciones básicas. Baste recordar, de pasada, la diferencia entre san Buenaventura y Alejandro de Hales, por un lado, y santo Tomás, por otro, para no hablar de Duns Escoto. Pero no es solo esto, ni tal vez lo más grave. Junto a la tradición latina está la masa ingente y espléndida de la tradición griega, de espíritu y actitudes intelectuales tan diferentes de las latinas. La identidad del dogma no ha sido obstáculo para estos dos cauces tan distintos de la teología" (69).

Pero además, Zubiri también defiende la necesidad de que la teología se nutra de otros saberes no teológicos. Así, lamenta el enfrentamiento eminentemente defensivo de la teología cristiana con la racionalidad moderna y las ciencias matemáticas y naturales, sociales e históricas (70). Por eso propone una suerte de conversión de la teología, para que aprenda a discernir y asumir la verdad que anida en esos ejercicios (a veces magníficos) de la razón humana y para que en caso alguno se confunda (como tantas veces ha ocurrido) con una crítica poco matizada de la modernidad y con una simple apología de los tiempos premodernos. Es prácticamente suicida identificar al cristianismo en bloque con una época como la medieval, una sociedad como la europea, o una cultura o civilización como la occidental:

(68) Vid. Zubiri (n. 13), pp. 457-462. Esta contraposición entre la tradición griega y la latina, que en caso alguno es excluyente, atraviesa todas las exposiciones que hace Zubiri del cristianismo (vid. Problema de la filosofía, n. 66, pp. 102-103; Historia, n. 1, p. 277; Cristianismo, n. 1, pp. 104$105,107,124-125,140-142,146,175-176,254$, etc.).

(69) Zubiri (n. 13), pp. 457-458.

(70) Vid. Zubiri, Historia (n. 1), pp. 278-279 y 305-322. 
"en el mundo antiguo la revelación se tuvo que hacer comprender a la razón griega. Después se ha podido ampliar la cosa [...], dirigiéndose a lo que podríamos llamar la razón europea o razón occidental. Pero, ¿está dicho que con esto estén agotadas las capacidades y la situaciones de comprensibilidad de una revelación que se apodera del hombre? ¿Dónde está dicho que otras mentalidades, otras civilizaciones, otros modos de pensar con otra tradición religiosa distinta no puedan ser los órganos a los cuales se dirija el depósito revelado para tener una comprensión mucho más rica y, desde luego, progresiva, respecto de la que tenemos nosotros? ¿Cómo se va a negar que hay muchos órganos mentales e intelectuales en los Brahmanes para poder aprehender en qué consiste la encarnación?";

"[...] aquello a lo que está más adherido y pegado en la historia el cristianismo, a saber, la razón griega y toda la teología especulativa, no pasa de ser una mentalidad como otra cualquiera. No está dicho en ninguna parte que mentalidades distintas de otros pueblos no sean en su hora el órganon adecuado para descubrir y actualizar nuevos aspectos de la revelación, completamente inadvertidos para la razón griega, para la razón europea” (71).

Y si en las ciencias se va encontrando la verdad, aunque no sea más que limitada y corregiblemente, el cristianismo no debe despreciar esa verdad, porque toda verdad participa de la Verdad que es el Verbo encarnado. Zubiri hace suyo el principio sentado por Atanasio:

"la segunda persona de la Trinidad, el Verbo, es la Verdad subsistente de Dios, y nada de lo que es verdadero es ajeno al Verbo. De ahí el principio que debe regular la presencia de la Iglesia frente a la ciencia moderna: el creyente no solamente tiene la posibilidad de hacer ciencia -es decir, mostrar de hecho que no son incompatibles-, sino que además tiene la obligación estricta y formal de ir descubriendo verdades científicas, que por el hecho de ser verdades son un reflejo y un trasunto de la Verdad subsistente de Dios en la persona del Verbo" (72).

A la vez, la teología actual ha de recurrir a saberes como la arqueología, la filología y la crítica, la sociología y la historia de las religiones, de la antigüedad, de los dogmas, de la propia Iglesia, etc., todos ellos esenciales para la recta conceptuación histórica y hermenéutica del cristianismo (73). Zubiri se detiene en el problema de la evolución de los dogmas o, mejor, del carácter esencialmente histórico de la revelación. A este respecto, basta decir que Zubiri siempre subraya la historicidad de la manifestación del Dios cristiano:

(71) Zubiri, Cristianismo (n. 1), pp. 475-476, e Historia (n. 1), pp. 322-323. Nótese el uso impropio que hace Zubiri en estos textos de la idea de mentalidad.

(72) Zubiri, Historia (n. 1), p. 279.

(73) Vid. Zubiri, Prólogo (n. 62), pp. xii-xiii, y Cristianismo (n. 1), p. 26. 
"decir que la revelación es histórica, por lo pronto, equivale a decir que la verdad subsistente, que es Cristo, es una verdad históricamente constituida [...] La historia no es otra cosa sino la revelación misma en acto [...] La historia es algo que pertenece a la constitución misma de la revelación [...] Desde este punto de vista, el Espíritu de la Verdad no es sino la historia misma de la revelación en tanto que historia [...] Puede decirse sin miedo a error que la historia de los dogmas no es sino la experiencia teologal e histórica de la revelación que tiene Cristo y, con él, su Iglesia [...] Hay que tomar la historia de los dogmas en la totalidad de la constitución del sôma tês aletheías, del cuerpo de la verdad. No cada dogma, sino el conjunto de todos esos dogmas en su concatenación interna, desplegándose y constituyéndose a lo largo de la historia [...] Dios no solo se da ad extra a las criaturas, sino que se da concreta e históricamente en la persona de Cristo. Y, por consiguiente, Dios no está solamente en la historia, sino que además está históricamente en ella” (74).

Contando con esta historicidad de la revelación y teniendo que recurrir a una multitud de saberes y tradiciones, la teología ha de ser, sin embargo, una única ciencia. Desde este punto de vista unitario, piensa Zubiri, la teología tendrá que reordenar sus tratados clásicos, pero también tendrá que crear ciertos tratados nuevos "que se propongan como problema algo así como descubrir las nervaduras que confieren su unidad al rico follaje de las diversas disciplinas teológicas" (75). Pero aún hay más. Y es que la teología no solo tiene que echar mano de todas sus tradiciones y aprender de los resultados que le suministran otras ciencias, sino que ha de establecer un vínculo permanente con la filosofía. ¿Por qué? ¿Cómo?

\section{FILOSOFÍA Y CRISTIANISMO}

La teología recurre a conceptos filosóficos para expresarse. También es cierto, a la inversa, que la filosofía occidental está entretejida de nociones teológicas. Mas, el horizonte filosófico que preside la obra de Zubiri, la fenomenología, es un horizonte no teológico. De ahí la necesidad de preguntarse por la legítima apelación que pudiera hacer la teología a la filosofía. La teología, en efecto, tiene planteado el grave problema de su relación con la filosofía. El principio parece claro: la teología no es filosofía, ni la una es sierva de la otra, pero la teología necesita de la filosofía para esclarecer muchos de sus propios términos. Las dificultades surgen cuando se desciende al concreto recurso que ha hecho la teología cristiana a la filosofía.

(74) Zubiri, Cristianismo (n. 1), pp. 459, 463, 482 y 483-485; vid. también Historia (n. 1), pp. 305-321, y Cristianismo (n. 1), pp. 454-613. No se crea que esta radical afirmación de la historicidad de la revelación cristiana equivale a la adopción de un punto de vista simplemente escéptico o relativista. El asunto es para Zubiri mucho más complejo, pues la misma historicidad es algo que se funda en Dios mismo: "sin embargo, la historicidad no es lo más radical del cristianismo. Lo radical es que la historicidad es un dar de sí por parte de Dios. Y este dar de sí real y formalmente consiste en deiformar aquello que crea y aquello en lo que se va a realizar": Cristianismo (n. 1), p. 486.

(75) Zubiri, Prólogo (n. 62), p. xiii. Allí mismo dice Zubiri que todas estas tareas no son asunto fácil y que "no ha nacido aún el genio teológico capaz de realizarlo". 
Por una parte, la teología clásica apeló a las filosofías de Platón, Aristóteles y Plotino. Para Zubiri esto no debe llevar a confusión; no hay que identificar las necesidades metafísicas de la teología cristiana con la filosofía de los griegos. Es lo que muestra la misma patrística griega. Si la teología necesita de la metafísica, hay que agregar que ante ella se abre una serie de posibles sistemas metafísicos, y que ninguno de ellos puede arrogarse la representación exclusiva del cristianismo. Entonces, la teología necesita de conceptos metafísicos, pero, sin embargo, no es solidaria de ninguna metafísica en particular, ni siquiera de la griega que servicios tan espléndidos le ha prestado:

"la metafísica griega no pasa de ser un modo, entre otros posibles, de entender la revelación. Puede incluso suministrar una serie de vocablos y de conceptos con que formular los dogmas. Pero estos conceptos no forman parte del dogma; solo es dogma lo que en ellos y con ellos se 'quiere decir'" (76).

Zubiri siempre dirá que la filosofía no se identifica sin más con las grandiosas creaciones griegas y que las definiciones dogmáticas no están vinculadas por el sentido técnico de los conceptos filosóficos que usan:

"porque la propia filosofía se ha enriquecido desde la época griega y la revelación y los dogmas no son solidarios de ninguna filosofía determinada; como es bien sabido, aun en aquellos casos en que los vocablos utilizados por la Iglesia procedan de una determinada filosofía, la Iglesia los utiliza en su sentido vulgar y no en el sentido estrictamente filosófico que poseían en los sistemas que los gestaron" (77).

Además, Zubiri irá más allá para denunciar que el resultado del encuentro entre las necesidades de la teología y las posibilidades de la filosofía griega ha sido muchas veces negativo. No se trata de que este encuentro constituya un sincretismo. Zubiri sabe que la filosofía griega le permite al cristianismo "una utilización de conceptos ajenos para con ellos actualizar y desenvolver internas posibilidades que existen en el cristianismo" (78). Más bien se trata de las limitaciones envueltas en la helenización misma del pensamiento cristiano (79). Tales limitaciones se deben a que la apelación teológica a la filosofía terminará por hacer que la filosofía adopte un horizonte teológico. Lo que se pierde con ello es la posibilidad de filosofar libremente. La emergencia del horizonte teológico impide el desarrollo de una filosofía pura y libre. Con todo, Zubiri destaca que la teología cristiana se vio forzada a ir más allá de las categorías griegas. Es la positiva influencia filosófica del cristianismo. La teología, se diría, tuvo que forjar filosóficamente ciertas nociones para mejor expresarse a sí misma. Así es como el cristianismo aportó ideas que la filosofía griega ni siquiera sospechó: la de Dios como persona, la del hombre como

(76) Zubiri, Cristianismo (n. 1), p. 28; vid. 262.

(77) Zubiri, Prólogo (n. 62), pp. xii-xiii.

(78) Zubiri, Historia (n. 1), p. 264; vid. 170-174.

(79) Vid. Zubiri, Cristianismo (n. 1), p. 230. 
persona creada, viador entre la nada y la plenitud de Dios, y la de creatio ex nihilo sui et subjecti, conforme a la cual la fundamentalidad de Dios adquiere un relieve masivo y tajante y su vinculación con el mundo no es lejana o indiferente sino estrictamente positiva (80). Que Dios se done personalmente a la persona humana deiformándola, agraciándola y haciéndose realidad plenaria accesible y accedida en una experiencia histórica de conformación por compenetración, es algo que la filosofía griega clásica no pudo siquiera concebir:

"la metafísica griega tropieza aquí con grandes limitaciones, que penden de la idea de la posible actuación de una potencia por un acto, o de una posible participación platónica de unas realidades respecto de otras. Pero sobre todo tiene una limitación fundamental y gravísima: la ausencia completa del concepto y del vocablo mismo de persona. Ha hecho falta el esfuerzo titánico de los capadocios para despojar al término hipóstasis de su carácter de puro hypokeímenon, de su carácter de subjectum y de sustancia, para acercarlo a lo que el sentido jurídico de los romanos había dado al término persona, a diferencia de la pura res, de la cosa. Es fácil hablar en el curso de la historia de la filosofía de lo que es la persona a diferencia de la res naturalis, por ejemplo en Descartes y en Kant sobre todo. Pero lo que se olvida es que la introducción del concepto de persona en su peculiaridad ha sido una obra del pensamiento cristiano, y de la revelación a que este pensamiento se refiere" (81).

La crítica de Zubiri, en todo caso, no se dirige solamente a la filosofía griega. Alcanza a la filosofía medieval y moderna, pues ellas son las que exprimen a fondo las posibilidades de una filosofía fundada teológicamente. Precisamente

"dentro de este horizonte teológico es donde se van a recibir las ideas griegas, y el organon de conceptos que ellas nos legan va a servir para entender y hacer inteligible no solo a Dios, sino también las cosas, dentro del horizonte de la nihilidad" (82).

Este es un punto en el que Zubiri parece aceptar, al menos parcialmente, la crítica de Heidegger: algo importante se ha perdido en la constitución onto-teológica de la metafísica y en la reunión del evangelio cristiano con la metafísica griega y la filosofía europea. Con las filosofías modernas, en particular, Zubiri mantiene una ambivalente relación. Le parece que la filosofía, como sucedió en la España del nacional-catolicismo franquista, no se puede atrincherar en un medievalismo para el cual lo moderno sea siempre sospechoso de desviación y error. De ahí que Zubiri dialogue constantemente con la filosofía moderna, dándole en muchos casos toda la razón. Pero esto diálogo tampoco es excesivamente entusiasta. Sabe-

(80) Vid. Zubiri, Los problemas fundamentales de la metafísica occidental (Madrid, Alianza 1994), pp. 77, 74-76 y 108-109.

(81) Zubiri, Dios (n. 45), p. 323. Este trozo parece una síntesis de la historia filosófica de la noción de persona que aparece en el artículo "En torno al problema de Dios".

(82) Zubiri (n. 80), p. 77. 
mos que para Zubiri el horizonte teológico pervive hasta la última gran filosofía moderna, que sería la de Hegel, y que por ello la filosofía nacida de Descartes es radicalmente impura. Más aún, Zubiri le dirige a los modernos los mismos reproches que a buena parte de la filosofía occidental: y es que en sus sistemas también laten las arraigadas tendencias a la entificación de la realidad y a la logificación de la intelección. Pero Dios no puede ser considerado como el ente par excellence ni su intelección ha de conformarse al modelo del lógos declarativo; son aspectos que la teología cristiana tendría que abordar enérgica y rigurosamente (83). Y todavía algo más. Zubiri le hace a la filosofía moderna una crítica más específica, en concreto la de haber llevado a cabo tres grandes sustantivaciones: la de la consciencia, la del espacio y el tiempo, y la del ser (84). Y ninguna de estas gigantescas operaciones filosóficas está fenomenológicamente fundada ni es apta para tratar metafísicamente de Dios ni teológicamente del Dios cristiano. La consciencia es la sustantivación de los actos conscientes, y con estos actos no se puede entender formalmente ni la intelección humana ni la divina. El espacio y el tiempo son la sustantivación de la espaciosidad y la temporalidad de las cosas, y forman parte (por el lado de la razón teórica) de ese dualismo entre el mundo sensible y el inteligible que es constitutivamente inapto para pensar en la realidad del hombre y a fortiori en la peculiar incorporación de Dios - por deiformación y por encarnación- al tiempo humano. Por fin, la sustantivación del ser y de su acontecimiento o Ereignis, según los términos del primer y del segundo Heidegger, tampoco es un buen punto de partida ni para pensar la primaria aprehensión de lo real ni tampoco para pensar al Dios cristiano, que si bien así deja de ser tratado como objeto más o menos disponible, a la vez pierde toda su concreción histórica y personal para convertirse en un acontecimiento puramente transcendental.

Todas estas críticas de Zubiri a las relaciones que ha mantenido la filosofía con el cristianismo lo llevan a dar un paso audaz. Y es que existe una posibilidad todavía poco explorada: la de que la teología cristiana recurra a la filosofía en un horizonte ni griego ni teológico. Pudiera decirse que, a ojos de Zubiri, la fenomenología constituye esa posibilidad. No se trata solo de que la teología cristiana disponga de otras posibles metafísicas; es que además podría disponer de unas filosofías no metafísicas sino primariamente analíticas. Es cierto que la fenomenología no siempre ha estado libre de las críticas recién apuntadas; de hecho, Husserl y Heidegger parecen ser destinatarios de varias de ellas. Pero la fenomenología no se confunde con la obra de estos autores. Lo que Zubiri insinúa, pero sin llevar a término, son las posibilidades filosóficas que le brinda la fenomenología a la teología. Múltiples son los temas que habría que abordar desde esta perspectiva (85). Pueden mencionarse, a título de ejemplo, los tres siguientes. Zubiri dice que en la raíz de la

(83) Vid. por ej. Zubiri, Cristianismo (n. 1), pp. 155-156.

(84) Vid. Zubiri (n. 13), pp. 15-16.

(85) Se ha sugerido, por ejemplo, que ideas tradicionales de enorme magnitud como las del Lógos de Dios, creación desde la nada y persona como sujeto, podrían ser renovadas teológicamente con el recurso a la fenomenología de Zubiri; vid. González, "La novedad teológica de la filosofía de Zubiri” (Madrid, FXZ 1994), pássim. Esta sería, pues, una forma concreta de reconstruir los datos revelados, y no solamente“-como en Heidegger- una denuncia genérica del influjo griego, medieval y moderno sobre el quehacer teológico. 
teología hay un logos teologal, algo que no es razón sino mero análisis del problema de Dios pero en tanto que él puede ser iluminado por el anuncio cristiano. También señala que Jesús ha de ser comprendido como la religación subsistente. E incluso apunta el desarrollo de una nueva conceptualización de la eucaristía. Veámoslo.

La religación constituye un hecho radical: el hombre está dominado por el poder de lo real. Es el problema teologal del hombre planteado por la religación. Este problema de Dios no es algo a demostrar o justificar racionalmente, sino que es un fenómeno que el logos puede mostrar a través del análisis de la realidad humana. Pues bien: el estudio de esta dimensión teologal en tanto que conditio sine qua non del cristianismo es justamente el cometido de lo que Zubiri llama logos teologal. El logos teologal no es el lógos teológico ni es tampoco el Lógos revelante:

"no se trata, en efecto, de hacer de la realidad humana objeto de consideración teológica, entre otras razones más hondas porque esto sería ya dar por supuesta la realidad de Dios. Toda consideración teológica es en este punto pura y simplemente una teoría, todo lo importante e incluso verdadera que se quiera, pero pura teoría. En cambio, lo que aquí buscamos es un análisis de hechos, un análisis de la realidad humana en cuanto tal, tomada en y por sí misma" (86).

La teología no admite en su seno solamente la reflexión metafísica acerca de la divinidad, sino también (y con antelación) el análisis fenomenológico de la dimensión teologal del hombre. El logos teologal no es ni metafísica ni teología, pero sí es análisis filosófico al que la teología no puede renunciar para llevar a cabo su propio cometido. La estructura intelectiva del logos teologal no es racional sino campal. No es razón sino riguroso logos. El logos teologal trata de hacer ver la posibilidad del imprevisible acontecimiento cristiano a partir del problema teologal del hombre. Zubiri dice esto al declarar que el cristianismo se inscribe en la experiencia teologal de la humanidad como religión de deiformación y que tal experiencia supone el descubrimiento campal y racional de Dios a partir del problema de Dios desencadenado por la religación (87). El evangelio cristiano es la elucidación de este problema; más aún, pretende ser la respuesta definitivamente verdadera a él. Esto no quiere decir que haya una línea de desarrollo, sin solución de continuidad, entre el problema de Dios y la revelación cristiana. Ahora se comprende mejor por qué una cosa es aquello que la razón puede por sí sola alcanzar, y otra distinta lo que la razón puede recibir y tratar de entender. El reinado de Dios proclamado e inaugurado por Jesús escapa a toda previsión racional. El evangelio es reflexionado teológicamente porque la intelección ha sido capacitada por la revelación. No por ello la experiencia cristiana, que es probación creyente y entrega, conformación y compenetración con Dios Padre, Hijo y Espíritu, es irracional. La teología afirma que el evangelio cristiano es perfectamente razonable, y que lo es porque responde efectivamente al problema teologal del hombre. Y sin embargo, esta respuesta no se puede derivar, deducir o excogitar del problema mismo. El ser humano solo puede

(86) Zubiri, Dios (n. 45), p. 371.

(87) Vid. Zubiri, Dios (n. 45), pp. 372-381, y Cristianismo (n. 1), pp. 614-617. 
conocer el anuncio evangélico como revelación libre y gratuita de Dios mismo. Entonces, aunque el evangelio es efectiva respuesta al problema de Dios, es siempre y solo una respuesta insólita, inesperada y sobreabundante. No hay proporción entre la búsqueda racional y la revelación de Dios, de manera que la razón solo conoce al Dios cristiano en la medida en que este se revela a sí mismo dándose personalmente al ser humano. Por eso el cristianismo, sin dejar de ser razonable, tiende a ofuscar a la razón, siendo por ello escándalo para los judíos y locura para los griegos (cf. 1 Co 1, 22-23) (88). La mostración de que la muerte en la cruz y la resurrección del Dios hecho hombre colmarían inesperada y felizmente la dimensión teologal del hombre: esto es lo que hace justamente el logos teologal. Sin ser aún teoría teológica, este logos apunta hacia la novedad irreductible y pasmosa del evangelio cristiano, pero lo hace a partir del análisis de la religación y la religión. Mientras el problema de Dios planteado por la religación descubre en la realidad humana su constitutiva dimensión teologal, la revelación cristiana es la pretensión de que esta dimensión teologal del ser humano se manifiesta radical y definitivamente como mórphosis divina, como deiformidad. El logos teologal no hace más que indicar que la pretensión cristiana se dirige precisamente al problema planteado por la religación. Esta dimensión teologal es, entonces, la posibilidad misma del cristianismo. Y la articulación reflexiva del cristianismo ya no es logos teologal sino lógos teológico. Por supuesto que el lógos teológico está fundado en el Lógos revelante que es Jesús, como hemos visto, pero uno y otro permanecerían totalmente ajenos al hombre si no supusieran esencialmente el problema de Dios. Si el hombre no tuviese un problema de Dios, no habría en la realidad humana dónde acomodar -por incómodo que sea- el anuncio cristiano. En suma, el logos teologal muestra que la deiformidad es para el hombre un posible despliegue de la religación que en todo caso consiste en una insólita respuesta al problema de Dios, mientras que el lógos teológico es la acogida formalmente racional de la revelación de esta deiformidad, su reflexión kerygmática, ostensiva y demostrativa, y su justificación especulativa, histórica y hermenéutica (89).

(88) Vid. Zubiri, Cristianismo (n. 1), pp. 46-64.

(89) Vid. Zubiri, Cristianismo (n. 1), pp. 35-39. Se ha propuesto una interpretación algo más complicada de las relaciones que según Zubiri guarda el saber teológico con el logos teologal y la metafísica monoteísta. Cuando se considera el cristianismo y el problema de Dios al cual se dirige el evangelio, habría que distinguir los niveles intelectivos en juego (logos analítico o razón teórica) del grado de compromiso confesional (filosófico o bien teológico) presente en cada caso, resultando del cruce de ambos criterios una compleja serie de aproximaciones intelectuales. Desde dicha perspectiva hay antes que todo (a) un análisis teologal de la religación al poder de lo real, que es materia del logos filosófico sin presupuestos confesionales. Luego (b) hay una teoría teologal del fundamento divino del poder de lo real, que ya es razón filosófica o metafísica también sin presupuestos confesionales. Enseguida (c) hay una teoría teológica del fundamento divino del poder de lo real, que es ya formalmente la razón con presupuestos confesionales o teológica. La teología, a su vez, puede ser (c1) teología teologal, que es la teología elaborada desde la perspectiva de su enraizamiento en el problema teologal del hombre. Esta teología teologal, en cuanto supone el análisis teologal y la teoría teologal, es justo la teología fundamental. Pero la teología también puede ser (c2) teología simpliciter, vale decir, teología sistemática con sus momentos exegéticos, históricos y especulativos: "en ella se prescinde de la inserción de los contenidos de la fe cristiana en la dimensión teologal del hombre, y se trata de justificar y esclarecer estos contenidos tomándolos en y por sí mismos": González, "El problema de la teología en Zubiri", en Cultura de Guatemala 17/5 (1996), p. 115; vid. en gral. 109-116. Solo convendría puntualizar que para Zubiri la teología fundamental o teologal, sin excluir a la teoría o 
Por este logos teologal, puede decir Zubiri que "Cristo es la consistencia teologal del relativo ser absoluto del hombre" (90). Zubiri se fija ante todo en la propia religación de Jesús: su religación es subsistente porque su realización personal envuelve a la persona del Hijo. La biografía de Jesús indica su religación incomparable:

"en el caso de Cristo habría que decir que, solamente porque él está incurso en la procesión generante del Verbo, su realización biográfica es justamente la religación subsistente. Y precisamente por ser religación subsistente es por lo que puede tener obediencia [...] Él estaba acatando la voluntad de Yahvé; aceptó la religión de Yahvé porque era precisamente la religión del Padre. Y precisamente porque en esa religión del Padre se plasma el acatamiento en que Cristo consiste constitutivamente, en tanto que religación subsistente. Desde este punto de vista, la biografía de Cristo fue para él, para él mismo ante todo, el despliegue de su constitutiva y subsistente religación" (91).

Zubiri complementa esta nota con otras dos: Jesús sería también la revelación subsistente y el sacramento subsistente. Las tres aluden a la biografía de Jesús como realización personal de su peculiar religación, destacando su obediencia, su oblación e inmolación por la muerte en la cruz y sus propias vicisitudes como signos sagrados de la voluntad del Padre:

"los tres conceptos a una (religación subsistente, revelación en acto y sacramentalidad subsistente) son los que a mi modo de ver constituyen justamente el sentido último y radical de lo que fue la biografía de Cristo para Cristo mismo que la vivió, a saber: la experiencia teologal, humana y biográfica de su propia filiación divina. Cristo quiso no solamente ser Hijo de Dios, sino que quiso de una manera formal y positiva saber lo que era necesitar de Dios, saber lo que era pedirle su ayuda. En definitiva, saber humanamente y sobre sus propios huesos, lo que es ser humanamente Hijo de Dios" (92).

Si se incluye la revelación y la sacramentalidad dentro de la religación y se atiende no solamente a la significación que tuvo la religación para la vida personal de Jesús sino a la significación que gracias a Cristo puede tener para la biografía de cualquier ser humano, puede verse en la religación subsistente un carácter esencial del cristianismo. He aquí la comprensión cristiana de la religación. La comprensión, según Zubiri, es la incorporación de las intelecciones ulteriores en la aprehensión primordial. La deiformación y la encarnación se incorporan, pues, a la religación, pues la realidad personal de Jesús envuelve al poder de lo real. Y a la inversa, este poder dominante de las cosas y de la persona humana queda 'comprehendido' por

metafísica teologal, se basa ante todo en el análisis teologal, mientras que la teología sistemática, aunque pueda recurrir al análisis teologal, dialoga sobre todo con la teoría teologal. Así se esclarece mejor la distinción entre teología fundamental y teología sistemática, puesto que esta última también recurre a la filosofía.

(90) Zubiri, Historia (n. 1), p. 258.

(91) Zubiri, Cristianismo (n. 1), pp. 306-307; vid. también 321.

(92) Zubiri, Cristianismo (n. 1), p. 312; vid. también 305-313. 
Jesucristo. Volver por incorporación desde la religión de deiformidad no es más que entender o comprender el poder que religa a la realidad humana y a todas las cosas. El hombre queda retenido en el poder de lo real que ahora es entendido como poder deiformante del Dios encarnado, muerto y resucitado. La vuelta a la religación desde el campo y el mundo supone, entonces, tanto el sentido campal de Dios como el esbozo racional de su coherencia metafísica, y supone -aún más- un acto de fe razonable en la revelación de Dios en Cristo gracias a la cual el hombre resulta constitutivamente deiformado. La comprensión de la religación desde el cristianismo lleva a decir que Jesús es la religación filial subsistente (93). Ya no es solo la religación característica de la biografía de Jesús, sino la religación de cualquier ser humano por la vida de Cristo en él (94). Comprensión no es tan solo un análisis de la posibilidad inusitada y revelada del cristianismo emergiendo desde la religación, que eso es el logos teologal, sino la articulación ya realizada entre el cristianismo y la religación y, por ende, entre la teología cristiana y la aprehensión primordial del poder religante de lo real. Zubiri dice que la religación subsistente, en cuanto rasgo de la biografía de Jesús, es "un concepto teologal, anterior a toda teología, y que está en las fronteras de la exégesis" (95); ampliando su significación para que abarque a la religación del hombre entendida desde el evangelio, habría que decir más bien que es un concepto comprensivo: es entender la religación precisamente a partir de la experiencia cristiana.

La mayor novedad en la interpretación que hace Zubiri del cristianismo, como se ve, consiste en señalar que su origen revelado no obsta a su radicación en el problema de Dios planteado por la religación. El logos teologal muestra el hecho de que la revelación, sin dejar de ser el acontecimiento libre, gratuito y misterioso de la donación personal de Dios, se dirige al hombre en tanto que religado por el poder de lo real. Así, el cristianismo es la revelación de Dios mismo en Jesús que la razón recibe, que trata de entender como la religión de deiformación, y de comprender como esa peculiar plasmación de la religación que es la religación subsistente. Zubiri todavía fue más allá y pretendió alguna vez una conceptuación metafísica de uno de los signos más característicos del cristianismo: la cena de Jesús. Es lo que intenta en la conferencia "Reflexiones teológicas sobre la eucaristía", de 1981. Su conceptuación es metafísica tanto en sentido analítico e intramundano como en sentido teórico y explicativo. Supone de todas formas el logos teologal, que muestra cómo la revelación cristiana se dirige al problema de Dios que todo hombre tiene y es. También, supone la comprensión del cristianismo como religación subsistente. La conceptuación de la eucaristía es, a la vez, fenomenológica y propiamente metafísica. Se diría que Zubiri señala en este texto in actu exercito cómo es que el lógos teológico, aunque no tenga por qué identificarse con la metafísica clásica, sin embargo, tiene necesidad de alguna conceptuación metafísica. Pues bien: Zubiri afirma la presencia real de Jesús en el pan eucarístico, pero diciendo que ella no se debe a una conversión por transubstanciación al modo clásico, sino que la propia presencia es el fundamento de la conversión por 'transubstantivación', esto es, por cambio de

(93) Vid. Zubiri, Cristianismo (n. 1), p. 262.

(94) Vid. Zubiri, Cristianismo (n. 1), p. 421.

(95) Zubiri, Cristianismo (n. 1), p. 307. 
condición y sentido de la misma sustancia material. La sustantividad aplicada al pan como cosa-sentido, como alimento y principio de vida, sería una noción analítica más idónea para concebir la misteriosa presencia de Cristo en el pan eucarístico. En palabras de Zubiri:

"Cristo es principio de nuestra vida espiritual. En cuanto tal, pertenece en modo constructo a las cosas-sentido, pues es alimento. Ahora bien, el pan no tiene la condición de poder constituir alimento espiritual. Pero la presencia de Cristo, dejando intactas las propiedades de la nuda realidad del pan, confiere a este una nueva condición. Abre la unidad clausurada y total de la sustantividad del pan-alimento a una unidad superior, a la unidad de Él mismo. Entonces el pan, conservando lo que clásicamente se llamaba sustancia, ha perdido su sustantividad y su condición y ha adquirido una condición de alimento de que antes carecía: la condición de ser alimento espiritual. La unidad del cuerpo de Cristo es ahora lo que constituye la unidad de la sustantividad del pan-alimento. La sustantividad del pan consagrado es así la sustantividad divina de Cristo mismo [...] La presencia real de Cristo ha cambiado la condición del pan. Por consiguiente, la conversión del pan consagrado no es transubstanciación, sino transubstantivación [...] Entonces hay que preguntarse qué relación hay, digámoslo así, entre esta conversión de sustantividad y la presencia real. La metafísica clásica ha pensado que la presencia real es una consecuencia de la conversión [...] Modestamente, pienso de otra manera. Creo que la conversión es la consecuencia de la presencia real del cuerpo de Cristo en el pan-alimento [...] Solo porque Cristo está presente en el pan, este pan, como sustantividad de alimento, ha perdido sustantividad material y ha adquirido sustantividad de alimento espiritual. Por la presencia real de Cristo el pan se convierte ratione alimenti" (96).

Pero no solo eso. Zubiri recurre a las nociones de actualidad y de corporeidad, para añadir que el modo de esta presencia real es una 'transactualización'. Jesús toma al pan-alimento como principio de su propia actualidad corpórea, de manera que el pan significa sacramentalmente el cuerpo de Cristo como alimento espiritual para el ser humano. Dice Zubiri:

"cuerpo es el principio no solo intrínseco, sino también formal de Cristo: por esto sôma puede significar 'yo mismo'. Pero en virtud de este principio formal y radical, Cristo puede 'extender' (perdóneseme el verbo) su propia actualidad formal, puede modalizar ulteriormente su principio de actualidad asumiendo el pan-alimento como principio de actualidad. Es una modalización, pero ulterior: Cristo tiene su cuerpo aunque no hubiera eucaristía. El pan en cuanto pan-alimento no es el cuerpo formal de Cristo. Cristo, por su propia razón formal, no es pan-alimento. Lo que es modalmente idéntico al cuerpo de Cristo es el pan-alimento como principio de actualidad de

(96) Zubiri, Cristianismo (n. 1), pp. 405-407; vid. en gral. 398-407. 
Cristo. El pan-alimento como momento de actualidad intrínseca está fundado en el cuerpo de Cristo como momento formal de la realidad de Cristo. Es la misma actualidad, pero modalizada como alimento. Esta 'extensión' es a mi modo de ver el punto preciso del misterio eucarístico en cuanto misterio: Cristo es tan actual en el pan como en su persona, pero es actual en el pan porque ya es actual en su persona [...] Que Cristo 'tome' el pan significa, pues, que Cristo hace de la actualidad del pan principio de su propia actualidad" (97).

Zubiri dice que esta es la esencia de la eucaristía. Empero, todavía agrega que su razón formal no se agota en esta presencia de Jesús por transubstantivación y transactualización en el pan como alimento, sino que constituye además "la forma suprema de la vida de Cristo" en el creyente (cf. Jn 6, 53-54 y Mt 26, 26) (98). La eucaristía es el banquete de unas personas que forman comunidad por su especial comunión con Jesús. Este misterio de comunión es una rigurosa incorporación al cuerpo de Cristo en cuya virtud cada comensal configura su propio ser a partir del ser mismo de Jesús. Así lo expresa Zubiri:

"la eucaristía es banquete, es ágape, y este ágape consiste en comunión personal con Cristo, y derivativamente en la comunión personal con los demás. La actualidad común de los comensales en el banquete eucarístico es unidad personal de todos ellos en la actualidad personal de Cristo [...] Los partícipes del ágape, al adquirir una actualidad con Cristo, forman, por tanto, cuerpo con él, y en su virtud su comunión personal con Cristo es precisa y formalmente incorporación al cuerpo de Cristo. Y como todos forman un mismo cuerpo con Cristo resulta, como nos dice san Pablo, que todos somos con-corpóreos en Cristo [...] Y como cuerpo es la actualidad del 'yo mismo' en la realidad, resulta que esta incorporación consiste en que cada partícipe del ágape es 'yo mismo', siendo yo en y por el Yo de Cristo. Todo cristiano es otro Cristo" (99).

Como se ve, toda esta reflexión teológica está anclada en las nociones de sustantividad, actualidad, corporeidad y yo. Son nociones originariamente fenomenológicas, pero que ahora -cuando se intenta dar razón del significado de la cena de Jesús- adquieren un estatuto metafísico, porque se convierten en esbozos de la realidad profunda independientemente de la aprehensión, y teológico, pues los tales esbozos se insertan en unas razones confesionalmente orientadas acerca del evangelio cristiano. Zubiri resume este esquema de lo que es la eucaristía diciendo que "la vida de Cristo en nosotros es una vida que emerge de Cristo (alimento) por transubstantivación, en forma de actualidad corpórea que consiste formalmente en la incorporación a Cristo" (100). El logos teologal podrá ver aquí que la eucaristía

(97) Zubiri, Cristianismo (n. 1), pp. 415-416; vid. en gral. 407-416.

(98) Zubiri, Cristianismo (n. 1), p. 416.

(99) Zubiri, Cristianismo (n. 1), p. 420; vid. en gral. 416-420.

(100) Zubiri, Cristianismo (n. 1), p. 421. 
es el misterio sacramental de la religación subsistente, es decir, el banquete en el que el poder de lo real toma cuerpo en el pan modalizado como principio de actualidad de Jesús y, por tanto, como alimento espiritual para los que se reúnen en su nombre. La cena de Jesús es, en todo caso, un ejemplo. Pareja operación de radicalización fenomenológica y depuración metafísica podría realizarse con todo el mundo sacramental y, en general, con los demás capítulos de la dogmática cristiana.

\section{CONCLUSIÓN}

Para Zubiri, Dios es el concepto internamente coherente de la realidad plenaria, única y personal, simple y eterna, a se, omnipotente, omnisciente y buena. $\mathrm{Si}$ se sigue este hilo argumentativo, entonces la coherencia externa de dicha concepción con los conceptos actuales que la razón humana puede hacerse del cosmos, del hombre y del mal natural y moral, permite afirmar de manera justificada que la realidad divina probablemente existe. El resultado de estas inquisiciones conceptuales es que la imagen monoteísta de Dios tiene un cierto privilegio racional ante las demás religiones y actitudes fundamentales respecto del problema de Dios. Esto equivale, según Zubiri, a la mejor verificación histórica de la vía monoteísta, que si como experiencia de compenetración conoce altibajos y perversiones, sin embargo, no es nunca una probación aberrante ni deforme. Solo hasta este punto puede llegar la razón; en adelante las distintas vías, sin dejar de ser razonables, se basan ante todo en una opción creyente. La mentalidad filosófica ya no puede argumentar imparcialmente dentro de la vía monoteísta a favor del mejor derecho de una u otra religión monoteísta. Se abre paso, entonces, la mentalidad teológica, que también argumenta con la razón pero de manera confesionalmente orientada. Zubiri opta aquí por el cristianismo, llevando cabo una teología fundamental que supone la verdad de la revelación de Dios en Jesús. El privilegio del cristianismo implica que es la religión radicalmente verdadera, aunque esta su verdad sea inclusiva y admita que las demás vías religiosas y no religiosas puedan ser más o menos adecuadas y verdaderas. La religión cristiana, en todo caso, necesita de una reflexión pre-teológica: de un logos teologal que muestre cómo esta vía de la deiformidad y la encarnación ha sido revelada como respuesta imprevisible e inesperada al problema de Dios que anida en todo ser humano. A la vez, necesita de una fenomenología que permita al lógos teológico discernir mejor sus propias relaciones con la metafísica antigua, medieval y moderna y, cada vez que sea necesario, utilizar unos mejores conceptos filosóficos para sistematizar los dogmas básicos de la revelación. De ahí que el núcleo más original de la filosofía de la religión de Zubiri penda de su 'noología' o fenomenología de la inteligencia, vale decir, de la religación y de la compleja estructura intelectiva de la religión que constituyen la raíz de lo sagrado y de todo sentido religioso y, por fin, de la mostración del concepto monoteísta de la divinidad y del propio cristianismo in statu nascendi a partir del problema teologal del hombre. 


\title{
RESUMEN
}

El autor trata de reconstruir las presuposiciones filosóficas del quehacer teológico característicamente cristiano sobre la base de los rasgos filosóficos envueltos en la teología de Zubiri. Por ello aborda en qué sentido cabe hablar de un privilegio del cristianismo frente a las demás vías religiosas, cuál es el núcleo esencial y radical de le fe cristiana, de qué manera es posible conocer aquel carácter formal del cristianismo y, por fin, cómo pueden caracterizarse -al interior de ese conocimiento- las relaciones del cristianismo con la filosofía.

Palabras clave: Zubiri, teología, filosofía, cristianismo.

\begin{abstract}
The author tries to reconstruct the philosophical presuppositions of the distinctively Christian theological activity on the basis of philosophical traits involved in the theology of Zubiri. Therefore addressed in what sense one can speak of a privilege Christianity over other religious paths, which is the core and root of Christian faith is, how it is possible to know that a formal nature of Christianity and, finally, how can characterized -inside this knowledgerelations of Christianity with philosophy
\end{abstract}

Key words: Zubiri, theology, philosophy, Christianity. 
